\title{
PANICOIDEAE (POACEAE) NO PARQUE ESTADUAL DE IBITIPOCA, MINAS GERAIS - BRASIL ${ }^{1}$
}

\author{
RAVENA DIAS-MELO, FABRÍCIO MOREIRA FERREIRA \\ $\&$ RAFAELA CAMPOSTRINI FORZZA
}

J ardim B otânico do Rio de J aneiro, Rua Pacheco Leão 915, 22460-030 - Rio de J aneiro, RJ, B rasil. e-mail: rafaela@ jbrj.gov.br

\begin{abstract}
A bstract - [Panicoideae (Poaceae) from the Parque Estadual de I bitipoca, M inas G erais, B razil]. The Parque Estadual do I bitipoca is situated in the south-east of M inas Gerais $\left(21^{\circ} 40^{\prime}-21^{\circ} 44^{\prime} \mathrm{S}\right.$ and $\left.43^{\circ} 52^{\prime}-4^{\circ} 55^{\prime} \mathrm{W}\right)$ and covers about 1.488 hectares of Serra do Ibitipoca. The average altitude of the Park is 1.500 meters, the highest peak is the L ombada, with 1.784 meters. The predominant vegetation in the area is campo rupestre, but there also enclaves of forest. The climate is mesotermic humid with dry winters and mild summers. The Panicoideae are represented by 43 species and 17 genera. A mongst them, the largest genera are Axonopus (7 spp.) and Paspalum (7 spp.), Panicum s.l. (6 spp.) and Andropogon (5 spp.). M ost species found at the Park are widely distributed through South A merica and some of them are pantropical, but always associated with open habitats. M elinis minutiflora (capim-gordura), a weed, founded where visitation is intense. Descriptions, identification keys and illustrations to helpful in the identification of taxa are presented.
\end{abstract}

\begin{abstract}
Resumo - [Panicoideae (Poaceae) no Parque Estadual de Ibitipoca, M inas Gerais - Brasil]. 0 Parque Estadual do Ibitipoca localiza-se no sudeste de M inas Gerais ( $21^{\circ} 40^{\prime}-21^{\circ} 44^{\prime} \mathrm{S}$ e $43^{\circ} 52^{\prime}-43^{\circ} 55^{\prime} \mathrm{W}$ ) e abrange 1.488 hectares da Serra do Ibitipoca. A altimetria média nos domínios do Parque é de 1.500 metros, sendo o pico mais alto da Serra, a Lombada, com 1.784 metros. A vegetação predominante na área é o campo rupestre com enclaves de florestas. 0 clima é mesotérmico úmido com invernos secos e verões amenos. Panicoideae está representada na área por 43 espécies e 17 gêneros. D entre eles destacam-se Axonopus ( 7 spp.) e Paspalum (7 spp.), Panicum s.l. (6 spp.) e Andropogon (5 spp.). A maioria das espécies encontradas no Parque distribui-se amplamente pela A mérica do Sul e algumas são pantropicais, mas sempre associadas a cerrados, campos rupestres e al gumas a ambientes florestais. Destaca-se ainda a ocorrência de M elinis minutiflora (capim-gordura), invasora, encontrada nos locais onde a visitação é intensa. São apresentadas descrições, chaves de identificação e ilustrações para auxiliar na identificação dos táxons.
\end{abstract}

Key words: Gramineae, M antiqueira, campo rupestre, flora

\section{Introdução}

Os representantes de Poaceae são componentes fundamentais em grandes ecossistemas, como as savanas, cerrados e campos, além de serem de extrema importância na alimentação humana. Destacam-se não só entre as monocotiledôneas, mas também entre as fanerógamas devido ao grande número de espécies (ca. 10.000 espécies e 793 gêneros) (Watson \& Dalwitz 1992). No B rasil, Poaceae está representada por cerca de 1.370, espécies agrupadas em 197 gêneros, distribuídas por todos os ecossistemas. Este número representa mais de $13 \%$ da diversidade total da família (Burman 1985).

Podem ser facilmente reconhecidas por apresentarem foIhas dísticas com bainha aberta, na maioria das vezes por- tando uma lígula, além de colmos com nós e entrenós bem marcados e inflorescências reunidas em unidades básicas chamadas espiguetas (J udziewicz 1990). 0 monofiletismo de Poaceae é fortemente sustentado por estudos morfológicos e moleculares, tendo como sinapomorfias a presença de fruto do tipo cariopse, um embrião altamente modificado com posicionamento lateral e canais de intraexina no grão de pólen (GPW G 2001).

Em 1970, K rieger \& Sucre (dados não publicados) elaboraram, na forma de relatório técnico, o que podemos considerar a primeira listagem para a Serra do Ibitipoca, onde 14 espécies de Poaceae e comentários sobre a distribuição destas na área foram apresentados. 0 primeiro levantamento especificamente tratando da família no Parque foi realizado por Oliveira (1992) que referiu 23 espécies, agrupadas em

${ }_{1}^{1}$ Parte da dissertação da primeira autora, apresentada ao Programa de Pós-G raduação do J ardim B otânico do Rio de J aneiro. 
16 gêneros. N este trabal ho, foram catalogados apenas 17 espécies e 11 gêneros de Panicoideae. A ndrade \& Sousa publicaram em 1995 uma lista preliminar sobre a flora do Parque e neste trabal ho surpreendentemente apenas oito espécies de Poaceae são citadas, e destas, apenas cinco Panicoideae.

0 presente estudo tem por objetivo ampliar o conhecimento sobre a real diversidade das Poaceae no Parque Estadual do Ibitipoca, apresentando o tratamento taxonômico das Panicoideae ocorrentes na área; indicar a distribuição geográfica das espécies, além de gerar informações para auxiliar no plano de conservação e manejo da U nidade.

\section{M aterial e M étodos}

A Serra de Ibitipoca está situada no sudeste de M inas Gerais e faz parte do Complexo da M antiqueira com relevo caracterizado pelas escarpas altas entre $1.200-1.800 \mathrm{~m}$ de altitude. 0 clima na região é do tipo $C w b$, mesotérmico úmido, com verões amenos e invernos secos, preci pitação média anual de $1.532 \mathrm{~mm}$ e temperatura média de $18,9^{\circ} \mathrm{C}$ (CETEC 1983). O Parque Estadual de Ibitipoca (PEIB) possui uma área de 1.488 ha. da Serra e inclui trechos dos municípios de Santa Rita de Ibitipoca e Lima Duarte $\left(21^{\circ} 40^{\prime}-21^{\circ} 44^{\prime} \mathrm{S}\right.$, $43^{\circ} 52^{\prime}-43^{\circ} 55^{\prime} W$ ). Diversas propostas de denominação para os tipos vegetacionais ocorrentes no Parque foram apresentadas por distintos autores, não havendo um consenso entre os mesmos. As denominações mais adequadas às fisionomias do Parque são as propostas de A ndrade \& Sousa (1995) para os campos e de Fontes (1997) para as florestas. Para maiores detalhes sobre o Parque ver M enini N eto et al. (2007a, b).

As espécies foram descritas adotando as terminologias propostas por Lawrence (1951), Radford et al. (1974) e Longhi-Wagner et al. (2001). As descrições abrangem especialmente as características diagnósticas de cada táxon. A distribuição geográfica tem por base dados bibliográficos e coleções examinadas. A s ilustrações foram el aboradas enfocando principalmente caracteres diagnósticos que auxiliam no reconhecimento das espécies. Os herbários consultados foram: BHCB, CES), RB, SP e SPF (acrônimos segundo Holmgren et al. 1990). Segue-se a proposta de GPWG (2001) para subfamílias e tribos, e para gêneros o 'C atal ogue of N ew World Grasses' (CNW G) (Zuloaga et al. 2003).

\section{Resultados e discussão}

Estudos real izados em áreas de campos rupestres da Cadeia do Espinhaço apontam Poaceae como uma das principais famílias, não só em diversidade, mas também em biomassa (Harley \& Simmons 1986, Giulietti et al. 1987, Harley 1995, Renvoize 1995, Zappi et al. 2003, Pirani et al. 2003).

$\mathrm{Na}$ Serra de Ibitipoca, área considerada disjunta da Cadeia do Espinhaço (Ferreira \& M agalhães 1977), a família também apresenta grande diversidade, principal mente em relação à Panicoideae que é a mais numerosa dentre as subfamílias de Poaceae e, em geral, apresenta maior riqueza de espécies em áreas de campo rupestre do que as demais. 0 presente estudo corrobora o que já foi observado para as demais serras do Espinhaço, sendo registradas 43 espécies de Panicoideae, distribuídas em 17 gêneros.

Estes resultados, somados aos de Ferreira et al. (2009a, b neste volume) que encontraram 30 espécies de gramíneas não Panicoideae, fazem de Poaceae a terceira maior família em diversidade no Parque, superada apenas por A steraceae (B orges 2008) e Orchidaceae ( $M$ enini $N$ eto et al. 2007a).

No extrato herbáceo das formações campestres do Parque destacam-se as espécies Axonopus brasiliensis, A. siccus, Echinolaena inflexa, Loudetiopsis chrysothrix, Panicum euprepes, Paspalum polyphyllum e, em especial, Trachypogon spicatus, que confere a coloração prateada dos campos nas áreas mais elevadas. A I gumas espécies de Panicoideae como I chnanthus inconstans, I. leiocarpus, O plismenus hirtellus, Panicum ovuliferum e Pseudoechinolaena polystachya, todas com via fotossintética C3, foram encontradas principalmente em matas ciliares ou capões. Espécies como Panicum rude e $P$. aristellum formam grandes populações à beira do rio do Sal to próximo à região da Prainha e ficam parcialmente submersas no período das chuvas. Chama atenção também espécies relacionadas à ambientes úmidos e de solo turfoso como Andropogon lateralis, A. macrothrix, Axonopus fastigiatus, Saccharum asperum e Steinchisma decipiens.

Espécies comuns em áreas antropizadas, Andropogon bicornis, A. leucostachyus, Digitaria ciliaris, D. horizontalis e Paspalum notatum, e exóticas, Digitaria fuscescens e M elinis minutiflora (capim gordura), foram encontradas no Parque, o que indica certo grau de distúrbio na área. K rieger \& Sucre em 1970 (dados não publicados) já apontavam a presença do capim gordura na área, além de expressarem sua preocupação com esse fato. A presença desta espécie pode ser um resquício do uso dos campos locais como pastos antes da criação do Parque (Salimena-Pires 1997).

\section{Chave para identificação das subfamílias de Poaceae ocorrentes no PEIB}

1. Plantas Ienhosas ou sublenhosas; fol has pseudopecioladas, geralmente articuladas com a bainha que persiste após a queda das lâminas vel has Bambusoideae

1'.Plantas herbáceas; fol has sem pseudopecíolo (presente em Panicum rude, porém sem articulação com a bainha).

2. Espiguetas com no máximo dois antécios, acrótonas, geralmente 0 antécio superior bissexuado e 0

inferior masculino ou neutro; glumas caducas com os antécios maduros (exceto em

Loudetiopsis chrysothrix) 
$2^{\prime}$. Espiguetas com um a muitos antécios, basítonas ou mesótonas, com ou sem antécios neutros apicais rudimentares ou pouco desenvolvidos; glumas persistentes na inflorescência após a queda dos antécios maduros (exceto em Polypogon elongatus).

3. Espiguetas 1-floras, basítonas, sem antécios neutros; lema com arista apical tripartida Aristidoideae

3'. Espiguetas 1-plurifloras, basítonas ou mesótonas, com ou sem antécios neutros; lema mútico ou com arista simples ou geniculada, apical, subapical ou dorsal.

4. Lema com o ápice profundamente 2-dentado, dentes prolongados em aristas laterais, com uma arista central geniculada, dorsal saindo da base dos dentes Danthonioideae

4'. Lema com ápice inteiro ou curtamente bidentado, dentes não prolongados em aristas laterais, mútico ou com arista apical simples, menos comumente dorsal.

5. Plantas microtérmicas; espiguetas basítonas, sem antécios neutros; lemas 5-pluri-nervados Pooideae

5'.Plantas megatérmicas; espiguetas basítonas ou mesótonas, com ou sem antécios neutros; lemas 1-3-nervados Chloridoideae

\section{PANICOIDEAE Link}

Panicoideae ocorre nas regiões tropicais e subtropicais, com ocasionais registros nas regiões temperadas (Chapman 1996). É um grupo monofilético, irmão de Centothecoideae e de acordo com o GPW G (2001) possui aproximadamente
3.270 espécies e divididas seis tribos: A ndropogoneae, A rundinelleae, Hubbardiaceae, Isachneae, Paniceae e Steyermarkochloeae. N este trabalho os autores não referem o número de gêneros aceitos na subfamília, mas segundo Clayton \& Renvoize (1986), Panicoideae engloba 292 gêneros.

\section{Chave para a identificação de tribos, gêneros e espécies de Panicoideae no PEIB}

1. A rticulação entre a ráquila e pedicelo da espigueta localizada acima das glumas, estas persistentes na inflorescência após a queda dos antécios maduros. Espiguetas acrótonas em tríades, adensadas entre si, simulando uma única espigueta ...... A rundinelleae (10. Loudetiopsis chrysothrix)

$1^{\prime}$. A rticulação entre ráquila e pedicelo da espigueta localizada abaixo das glumas, estas e os antécios maduros caem simultaneamente. Espiguetas acrótonas solitárias ou binárias, neste caso não simulando uma única espigueta.

2. Nó da ráquis com duas espiguetas, sendo a proximal séssil (geralmente bissexuada) e a distal pedicelada (geral mente neutra, às vezes bissexuada ou unisexuada); glumas de consistência mais rígida que a do antécio superior, este hialino. Entrenós da ráquis e pedicelos em geral densamente pilosos.

Diásporos com duas espiguetas

3. Espiguetas homógamas 6. Saccharum asperum

$3^{\prime}$. E spiguetas heterógamas.

4. Espiguetas com calo agudo e pungente, as sésseis masculinas, as pediceladas bissexuadas 9. Trachypogon spicatus

$4^{\prime}$. Espiguetas com calo obtuso, não pungente, as sésseis bissexuadas ou femininas, as pediceladas masculinas ou neutras.

5. Espatéola com um ramo florífero.

6. Gluma inferior da espigueta séssil plana ou côncava 5. Andropogon virgatus

6'. Gluma inferior da espigueta séssil convexa.

7. Ramos floríferos flexuosos na maturidade; espigueta pedicel ada neutra ...... 7. Schizachyrium condensatum

7'. Ramos floríferos eretos na maturidade; espigueta pedicel ada bissexuada $5^{\prime}$. Espatéola com dois ou mais ramos floríferos.

8. Inflorescências corimbiforme, com mais de 8 ramos 8. Schizachyrium tenerum 8'. Inflorescências al ongadas, com 2-7 ramos.

9. Espiguetas pediceladas desenvolvidas, masculinas 2 1. Andropogon bicornis

$9^{\prime}$. Espiguetas pediceladas rudimentares, neutras.

10. Espiguetas sésseis 2,5-3,2 mm compr.; aristas 1,7-4 mm compr.

10'. Espiguetas sésseis 4-6 mm compr.; aristas 10-16 mm compr. Andropogon lateralis

2 '. Nó da ráquis com espigueta solitária (bissexuada), às vezes 2-3 espiguetas (em grupos), se duas, ambas curtamente pediceladas (bissexuadas); glumas de consistência igual ou menos rígida que a do antécio 
superior, este não hialino. Entrenós da ráquis e pedicel os geral mente glabros ou esparsamente pilosos.

Diásporos com espigueta solitária

Paniceae

11. Inflorescência em panícula típica, laxa, contraída ou espiciforme e cilíndrica.

12. Lema inferior bífido, aristado; gluma inferior reduzida, ca. 1/5 do comprimento da gluma superior

28. Melinis minutiflora

12'. Lema inferior inteiro, mútico; gluma inferior desenvolvida, 1/4-1/2 do comprimento da gluma superior.

13. Lema superior alado na base da face ventral.

14. Lâminas foliares de base subcordada, não pecioladas; lema superior com al as de 0,3-0,7 mm compr., parcial mente aderidas à base do lema 25. Ichnanthus inconstans

14'. Lâminas foliares de base atenuada, curtamente pecioladas; lema superior com alas de 1,3-1,8 mm compr., não aderidas à base do lema 26. I chnanthus leiocarpus

13'. L ema superior não alado na base da face ventral.

15. Inflorescência em panícula contraída, espiciforme, cilíndrica; antécio superior papiloso

43. Steinchisma decipiens

15'. Inflorescência em panícula típica, laxa; antécio superior não papiloso.

16. Comprimento e largura da gluma inferior $(2,2-3,5 \times 1,2-2 \mathrm{~mm})$ subigual ou um pouco maior que o da gluma superior $(2,2-2,7 \times 1,2-2 \mathrm{~mm})$ e dos antécios superiores

$(2,5-3 \times 1,2-1,5 \mathrm{~mm})$

24. Homolepis glutinosa

16 '. Comprimento e largura da gluma inferior $(1-3 \times 0,3-1,7 \mathrm{~mm})$ menor do que 0 da gluma superior (1,3-4,8 x 0,6-2 mm) e do antécio (1,3-4,3 × 0,8-2 mm).

17. Gluma superior 8-nervada e lema inferior 7-nervado

17'. Gluma superior e lema inferior até 5-nervados.

18. Glumas e lema inferior aristulados

18. Dichanthelium superatum

18'. Glumas e lema inferior não aristulados.

19. Base da gluma inferior envolvendo a gluma superior

30. Panicum aristellum

9'. B ase da gluma inferior não envolvendo a gluma superior.

20. Lâminas foliares $10-25 \mathrm{~cm}$ compr., ápice

pungente

32. Panicum euprepes

20'. Lâminas foliares 1,7-11,5 cm compr., ápice não pungente.

21. L âminas foliares com base assimétrica; panículas

$10-13 \times 5-8,5 \mathrm{~cm}$

34. Panicum sellowii

$21^{\prime}$. L âminas foliares com base simétrica; panículas

$4,5-6 \times 2-5 \mathrm{~cm}$

31. Panicum cyanescens

11'. Inflorescência em panícula de ramos unilaterais espiciformes.

22. Gluma inferior presente, desenvolvida.

23. Fol has com pseudopecíolo

33. Panicum rude

23'. Fol has sem pseudopecíolo.

24. Gluma inferior aristada

29. Oplismenus hirtellus

24'. G luma inferior não aristada.

25. Gluma inferior 3-nervada, ápice apiculado, gluma superior com tricomas uncinados 42. Pseudechinolaena polystachya

25'. Gluma inferior 7-9-nervada, ápice acuminado; gluma superior com esparsos tricomas hirtos al guns de base tuberculada 23. Echinolaena inflexa

$22^{\prime}$. G luma inferior ausente ou, se presente, reduzida.

26. Gluma superior com face abaxial voltada para a ráquis.

27. Inflorescências com 5-16 racemos subverticilados

17. Axonopus siccus

$27^{\prime}$. Inflorescências com 2-4 racemos verticilados ou subverticilados.

28. Ráquis pilosa, tricomas tuberculados.

29. M argem da ráquis e espiguetas portando longos tricomas alvos ...... 12. Axonopus brasiliensis

$29^{\prime}$. M argem da ráquis com longos tricomas castanho-dourados e espiguetas

portando curtos tricomas, que caducam com a maturidade

11. Axonopus aureus

28'. Ráquis glabras ou glabrescente.

30. Gluma superior 2-(3)-nervada

14. Axonopus fastigiatus

30'. Gluma superior 4-nervada. 
31. Espiguetas 1,7-2 mm compr.; gluma superior com base comosa 15. Axonopus fissifolius

31'. Espiguetas 2-2,7 mm compr.; gluma superior não comosa.

32. Plantas cespitosas; gluma superior com ápice assimétrico, lema superior esparsamente papiloso com ápice papiloso 16. Axonopus polystachyus

32'. Plantas não cespitosas; gl uma superior com ápice simétrico, lema superior liso com curtos tricomas no ápice

13. Axonopus complanatus

$26^{\prime}$. Gluma superior com a face adaxial voltada para a ráquis.

33. Lema superior com margens recobrindo totalmente a pálea.

34. Lema inferior e gluma superior com tricomas claviformes

20. Digitaria corynotricha

$34^{\prime}$. L ema inferior e gluma superior pubescentes com tricomas seríceos.

35. Gluma inferior presente 19. Digitaria ciliaris

35'. Gluma inferior ausente.

36. Plantas $9-25 \mathrm{~cm}$ alt., inflorescências com 2-3 racemos 21.Digitaria fuscescens

$36^{\prime}$. Plantas $68-90 \mathrm{~cm}$ alt., inflorescências com 4-22 racemos 22. Digitaria horizontalis 33'. L ema superior com margens não recobrindo total mente a pálea.

37. Inflorescências com racemos conjugados, divergentes

38. Paspalum notatum 37'. Inflorescências com racemos alternos.

38. Gluma superior e lema inferior com a porção central hialina 36. Paspalum hyalinum $38^{\prime}$. Gluma superior e lema inferior uniforme.

39. Gluma superior com tricomas longos, 2-5 mm compr., nas margens

41. Paspalum polyphyllum

39'. Gluma superior glabra ou portando curtos tricomas, menores que $2 \mathrm{~mm}$ compr., nas margens

40. Gluma superior 5-nervada.

41. Plantas 114-140 cm alt.; espiguetas 2,3-2,7 x 1,5-1,7 mm; lema inferior 3-nervado 35. Paspalum dilatatum

41'. Plantas 35-70 cm alt.; espiguetas 2-2,2 x 1-1,2 mm; lema inferior 5-nervado 39. Paspalum nutans

40'. Gluma superior 3-nervada.

42. Inflorescências com 5-16 racemos; ráquis 0,4-0,7 mm larg.; espiguetas glabras ou glabrescentes 37. Paspalum juerguensii

42'. Inflorescências com ca. 21 racemos, ráquis 0,3-0,4 mm larg.; espiguetas vilosas 40. Paspalum paniculatum

\section{TRIBO ANDROPOGONEAE}

Andropogon L., Sp. Pl.: 1045. 1753.

Andropogon apresenta distribuição tropical e briga cerca de 100 espécies que ocorrem preferencialmente em vegetações savânicas e mais raramente nos campos das montanhas tropicais (Clayton \& Renvoize 1986). No Novo M undo são registradas 54 espécies (Zuloaga et al. 2003), das quais 28 são encontradas no B rasil (Zanin \& L onghi-Wagner 2006) e cinco ocorrem no PEIB.

1. Andropogon bicornis L., Sp. pl. 2: 1046. 1753.

Fig. 1. A-B.

Plantas perenes, 0,5-1,6 m alt., cespitosas. Lígula membranoso-ciliada; lâminas foliares $11-52 \times 0,2-0,5 \mathrm{~cm}$, lineares, face adaxial geralmente pilosa, face abaxial escabra na nervura mediana e próximo à região ligular com tricomas de ca. $4 \mathrm{~mm}$, ápice agudo, sem estreitamento na base, margem pilosa. Inflorescência 10-21 cm compr., corimbiforme, mais de 8 ramos floríferos, espatéolas evidentes, 2 ramos floríferos por espatéola, 2-4 cm compr., parcial ou total mente exsertos; entrenós da ráquis e dos pedicelos densamente pilosos, tricomas alvos, sedosos, 6-8 mm compr. E spiguetas sésseis 3-4 $\mathrm{mm}$ compr., bissexuadas, múticas; espiguetas pediceladas 0,7 $1,1 \mathrm{~mm}$ compr., rudimentares, neutras, as duas pedicel adas do ápice dos ramos desiguais, uma rudimentar e neutra, a outra desenvolvida e masculina, mútica. C ariopse não observada.

Material selecionado: 19.VI.1991, R.C. O liveira et al. 34 (CES), RB); 14.III.1996, L.G. Rodela AC-146 (CESJ); 30.III.2004, R. DiasMelo et al. 163 (K, RB e SP).

Distribuição geográfica e habitat: ocorre desde o M éxico até a A rgentina. No Brasil há registro para todos os esta- 
dos sendo a única exceção o Rio Grande do N orte (Zanin \& Longhi-Wagner 2006). A. bicornis é comum em locais alterados como beiras de estradas e também áreas de cerrado, campo rupestre, locais brejosos, bordas de matas e terrenos arenosos. No PEIB ocorre em populações esparsas na trilha da Prainha para o M onjolinho, aos 1.377 m de altitude. Também ocorre na Lagoa Seca, que é um local úmido sujeito à inundação.

2. Andropogon lateralis $\mathrm{Nees}$, in $\mathrm{M}$ art. \& Eichl., $\mathrm{Fl}$. bras. enum. pl. 2(1): 329. 1829.

Fig. 1. C.

Plantas perenes, 0,5-1 m alt., cespitosas, com rizomas curtos. Lígula membranoso-ciliada; lâminas foliares 7-48 $x$ 0,1-0,7 cm, lineares, planas ou involutas, face adaxial glabra, abaxial escabra, ápice obtuso a subagudo, margem com tricomas de ca. $1 \mathrm{~mm}$ compr., sem estreitamento na base, base com tricomas de ca. $5 \mathrm{~mm}$. Inflorescência 3-7 cm compr., 3-7 ramos floríferos por espatéola, 3-7 cm compr., conjugados ou subdigitados, exsertos da espatéola; entrenós da ráquis e pedicel os densamente pilosos, tricomas al vos, sedosos, 2-3 mm compr. E spiguetas sésseis 4-5 mm compr., bissexuadas, arista 5-8 mm compr.; espiguetas pediceladas 5-7 $\mathrm{mm}$ compr., desenvolvidas, masculinas, múticas. Cariopse não observada.

Material selecionado: 12.IX.1991, S.M .S. Verardo et al. S.n. (CEN n.v., CESJ 25367); 2.XI.1991, R.C. Oliveira 48 (CESJ); 20.XII.2003, F.M . Ferreira et al. 596 (CES) ); 26.X.2004, R. Dias-M elo et al. 185 (K, RB, SP); 26.X.2004, R. Dias-M elo et al. 188 (K, RB, SP).

Distribuição geográfica e habitat: espécie com ampla distribuição por toda a A mérica do Sul. No B rasil ocorre nos estados do A mazonas, Maranhão, Distrito Federal, Goiás, $M$ ato $G$ rosso, $M$ ato Grosso do Sul e de $M$ inas Gerais ao Rio Grande do Sul (Zanin \& Longhi-Wagner 2006). No PEIB ocorre na Ponte de Pedra, em mata ciliar e nas tril has para 0 Pião e na L agoa Seca, no campo rupestre.

3. Andropogon leucostachyus Kunth in Humb., B onpl. $\&$ K unth, N ov. gen. sp. 1: 187. 1816.

Fig. 1. D.

Plantas perenes, 0,7-1 m alt., cespitosas. Lígula membranosa; lâminas foliares 6-52 x 0,1-0,4 cm, lineares, face adaxial e abaxial escabras, ápice agudo, margem escabérula, sem estreitamento na base. Inflorescência 1,5-4,5 cm compr., 2-6 ramos floríferos por espatéola, 1,5-4,5 cm compr., conjugados ou digitados, exsertos das espatéolas; entrenós da ráquis e pedicelos densamente pilosos, tricomas alvos, sedosos, 4-6 mm compr. Espiguetas sésseis 2,5-3,2 mm compr., bissexuadas, geralmente aristadas, arista 1,7-4 mm compr., menos freqüentemente espiguetas múticas; espiguetas pediceladas 0,8-1,5 mm compr., rudimentares, neutras, múticas ou aristuladas. C ariopse não observada.
Material examinado: 22.II.1992, M. Eiterer s.n. (CES) 25717, RB); 20.XII.2003, F.M. Ferreira et al. 585 (CESJ, RB); 30.III.2004, R. Dias-M elo et al. 167 (K, RB, SP).

Distribuição geográfica e habitat: ocorre desde o M éxico até A rgentina, em áreas de cerrado, campo rupestre, campos hidromórficos, bordas de mata e locais alterados (Renvoize 1984, Zanin 2001a, Zanin \& Longhi-Wagner 2006). No PEIB foi registrada nas margens das trilhas e no camping, sempre no campo rupestre.

4. Andropogon macrothrix Trin., M ém. A cad. Imp. Sci. St.-Pétersbourg, Sér. 6, Sci. M ath. 2(3): 270. 1832.

Fig. 1. E-F.

Plantas perenes, $36-70 \mathrm{~cm}$ alt., cespitosas. Lígula membranoso-ciliada; lâminas foliares (2)3-15 x 0,1-0,4 $\mathrm{cm}$, lineares, planas, às vezes conduplicadas, face abaxial glabra, face adaxial escabra, ápice subagudo a bífido, margem da base glabra e do ápice escabérula, sem estreitamento na base. Inflorescência 3-6 cm compr., com 2-4 ramos floríferos por espatéola, 3-6 cm compr., conjugados ou subdigitados, exsertos da espatéola; entrenós da ráquis e pedicelos densamente pilosos, tricomas alvos, sedosos, 2-4 mm compr. E spiguetas sésseis, 4-6 mm compr., bissexuadas, arista 10-16 mm compr.; espiguetas pediceladas 3-4 mm compr., reduzidas, neutras, múticas ou aristuladas. C ariopse não observada.

Material selecionado: 3.XI.1991, R.C. Oliveira 60 (CES), RB); 19.VI.1991, R.C. Oliveira et al. 15 (CESJ, RB). 22.II.1992, M. Eiterer S.n. (CESJ 25719); 24.III.2001, M.A. Heluey et al. 82 (CES)); 20.XII.2003, F.M . Ferreira et al. 608 (CESJ, FL OR n.v., RB); 4.II.2004, R. Dias-M elo et al. 146 (K, RB, SP); 30.III.2004, R. Dias-M elo et al. $176(\mathrm{~K}, \mathrm{RB}, \mathrm{SP})$.

Distribuição geográfica e habitat: ocorre na A rgentina, Bolívia, Paraguai, U ruguai e no Brasil, do M ato Grosso ao Rio Grande do Sul em áreas de campo, cerrado, campo rupestre, em borda de floresta ombrófila densa e com muita freqüência em locais alagados (Renvoize 1984, Zanin \& Longhi-Wagner 2006). No PEIB foi registrada em vários locais entre fendas de rocha, em solo arenoso ou em campo encharcável, sempre em local ensolarado.

5. Andropogon virgatus Desv. ex Ham., Prodr. Pl. Ind. Occid. 9. 1825.

Fig. 1. G-H.

Plantas perenes, $36-50 \mathrm{~cm}$ alt., cespitosas. Lígula membranoso-ciliada; lâminas foliares 6,5-14 x 0,1-0,3 cm, lineares, conduplicadas, ambas as faces glabras, ápice subagudo a obtuso, margem levemente ciliada a escabra, sem estreitamento na base. Inflorescência $12-15 \mathrm{~cm}$ compr., congesta um ramo florífero por espatéola, 6-10 mm compr., parcialmente exsertos das espatéolas, estas castanhas, numerosas, vistosas; entrenós da ráquis e pedicelos esparsamente pilosos. E spigue- 


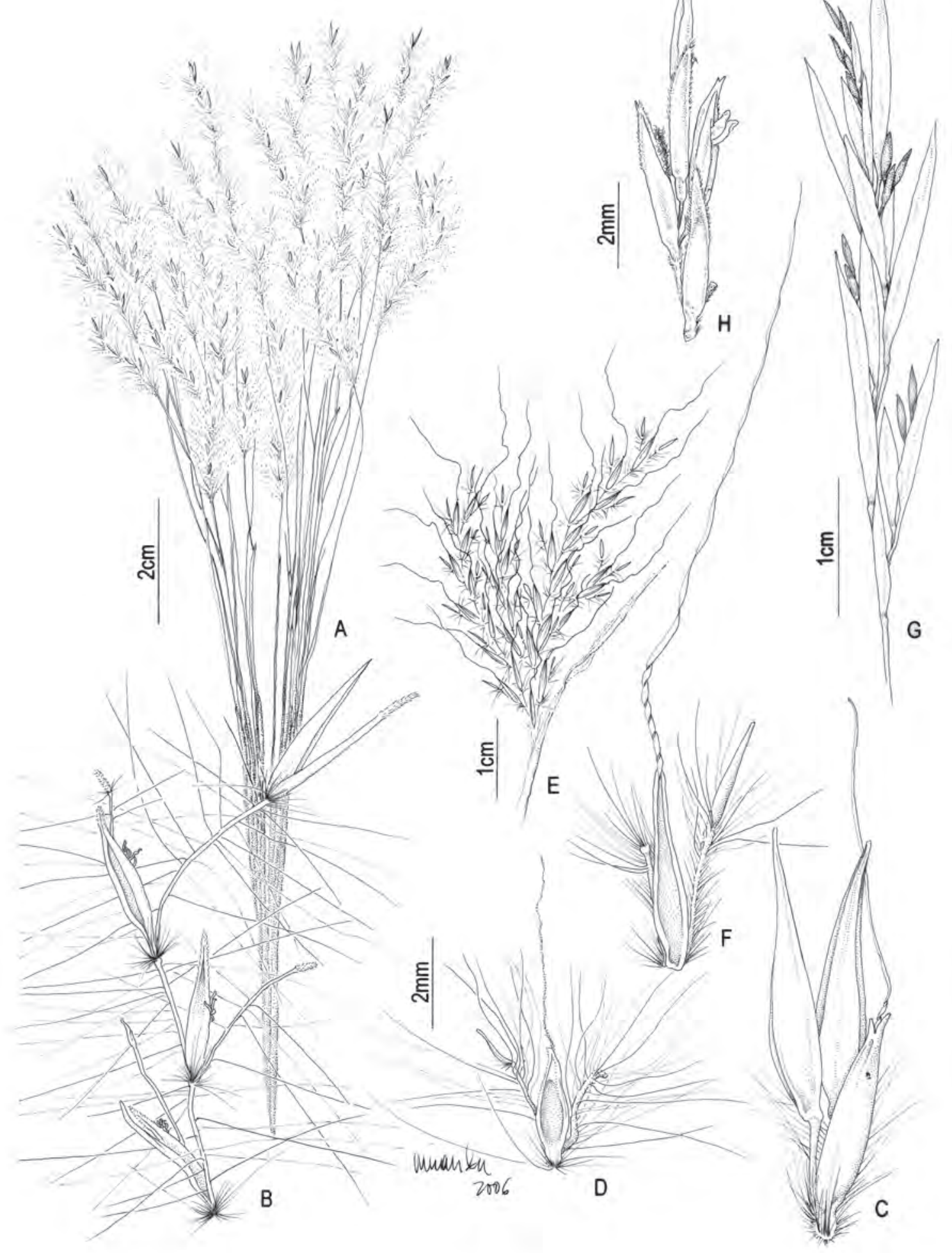

Fig. 1. A-B Andropogon bicornis: A . inflorescência, B. pares de espiguetas; C. A. lateralis: par de espiguetas; D. A. leucostachyus: par de espiguetas; E-F A. macrothrix: E. inflorescência, F. par de espiguetas; G-H A. virgatus: G. inflorescência, H. pares de espiguetas. (A-B DiasMelo 163; C Dias-M elo 16; D Dias-M elo 167; E-F Oliveira 15; G-H Ferreira 686). 
tas sésseis e pediceladas de tamanho igual, 3,5-4 mm compr., não aristadas, ambas desenvolvidas, as sésseis pistiladas e as pediceladas masculinas. Cariopse não observada.

Material examinado: 30.III.2004, F.M. Ferreira et al. 686 (RB, UFP n.v.).

Distribuição geográfica e habitat: ocorre do M éxico até a A rgentina e U ruguai, sendo comumente encontrado em locais brejosos, ou em solo arenoso temporariamente alagado. (Zanin \& Longhi-Wagner 2006). No PEIB forma grandes touceiras acima dos $1.400 \mathrm{~m}$ de altitude, porém, é pouco freqüente.

Andropogon virgatus pode ser facilmente confundida com espécies de Schizachyrium por apresentar um único ramo florífero por espatéola. Porém, em Andropogon a gluma inferior da espigueta séssil é plana ou côncava e em Schizachyrium esta é convexa.

Saccharum L., Sp. PI. 1: 54. 1753.

Saccharum possui entre 35-40 espécies distribuídas nas regiões tropicais e subtropicais, principalmente em margens de rios e vales (Clayton \& Renvoize 1986). A circunscrição atual do gênero é mais estrita, com apenas 14 espécies reconhecidas (Zuloaga et al. 2003). No PEIB, apenas uma espécie foi registrada.

6. Saccharum asperum (N ees) Steud., Syn. PI. Glumac. 1: 407.1854.

Fig. 2. A-B.

Plantas perenes, 1-2,5 m alt., cespitosas; nós pilosos. Lígula membranosa; lâminas foliares $10-86 \times 0,5-2,4 \mathrm{~cm}$, linear-lanceoladas, glabras ou levemente escabras em ambas as faces. Inflorescência contraída, $27-30 \mathrm{~cm}$ compr., rósea ou arroxeada quando jovem e esbranquiçada quando madura; entrenós da ráquis e os pedicelos pilosos, tricomas 1-4 mm compr., anel de tricomas 3-7 mm compr. na base da espigueta séssil. E spiguetas sésseis e pediceladas $4-5 \mathrm{~mm}$ compr., aristas de 5-7 mm compr., base com anel de tricomas de 4-5 mm compr.; glumas glabras, 2-3-nervada, ápice bífido, a inferior com margem escabra. Cariopse ca. 1,8 x 0,4 mm, castanho-escura.

Material examinado: 3.II.1993, R.C. Oliveira 145 (CES), RB); 21.XII.2003, F.M . Ferreira et al. 618 (CES), RB); 4.II.2004, R. DiasMelo et al. 145 (K, RB, SP); 18.I.2005, R.C. Forzza et al. 3930 (K, $M B M, R B, S P)$.

Distribuição geográfica e habitat: ocorre na Venezuela, Paraguai, A rgentina e B rasil (Filgueiras \& L erina 2001). Saccharum asperum é uma espécie associada a cursos d'água e locais brejosos. No PEIB, ocorre no L ago das M iragens próximo ao curso d'água e próximo ao M onjolinho, em local brejoso.
Schizachyrium N ees in M art. \& Eichl., Fl. bras. enum. pl. 2(1): 331. 1829.

Gênero com cerca de 60 espécies, distribuídas nas regiões tropicais e estendendo-se para as subtropicais (Renvoize 1984). Para o N ovo M undo são referidas 30 espécies (Zul oaga et al. 2003). Türpe (1984) cita 10 espécies para a A mérica do Sul. No PEIB, Schizachyrium está representado por duas espécies.

Este gênero é estreitamente relacionado a Andropogon seção Leptopogon, diferindo por apresentar um racemo por espatéola (Clayton \& Renvoize 1986). Tal caráter é compartilhado com al gumas espécies de Andropogon. A diferenciação pode ser feita pela gluma inferior da espigueta séssil plana ou côncava em Andropogon e convexa em Schizachyrium (Clayton \& Renvoize 1986).

7. Schizachyrium condensatum (Kunth) Nees, in M art. \& Eichl., Fl. bras. enum. pl. 2(1): 333. 1829.

Fig. 3. A-B.

Plantas cespitosas, 0,7-1 m alt.. Lígula membranosa; lâminas foliares 3-12 x 0,2-0,4 cm, lineares, planas ou involutas, face adaxial escabra ou ambas as faces glabras e escabras ao longo da nervura central, ápice agudo, margem escabra, sem estreitamento na base. Inflorescência com um ramo florífero por espatéola, 0,5-3,5 cm compr., ramos flexuosos na maturidade, parcialmente incluídos na espatéola, estas evidentes e numerosas; entrenós da ráquis e pedicelos pilosos, tricomas 1,5-2 mm compr., alvos e sedosos. E spiguetas sésseis 4-6 mm compr., bissexuadas, aristadas, gluma inferior convexa, glabra e lisa, sem nervuras no seu dorso, com ápice bífido e escabérulo; gluma superior comprimida lateralmente, uniquilhada, glabra, porém escabérula na porção da quilha, a nervura se prolonga no ápice da gluma em uma arístula; lema inferior hialino; lema superior com duas alas hialinas, aristado, arista geniculada, coluna ca. $6 \mathrm{~mm}$ compr., castanho-dourada, súbula ca. $9 \mathrm{~mm}$ compr., helicoidal, desenrolando-se do ápice para a base; espiguetas pedicel adas ca. $4 \mathrm{~mm}$ compr., neutras, rudimentares, escabérulas, aristadas, arista ca. $2 \mathrm{~mm}$ compr., pedicelo ca. $3 \mathrm{~mm}$ compr., piloso nas laterais, tricomas ca. $2 \mathrm{~mm}$ compr., alvos e sedosos. Cariopse castanho-dourada, com ápice bífido.

M aterial examinado: 13.III.2005, R. Dias-M elo et al. 231 (K, RB).

Distribuição geográfica e habitat: distribui-se por toda a A mérica do Sul (Türpe 1984), porém através dos dados de herbário constatou-se também a ocorrência desta espécie na A mérica Central e na Costa Rica. No B rasil, ocorre do Pará ao Rio Grande do Sul em cerrados, campos rupestres, campos secos com solos arenosos ou pedregosos e em locais alterados (Zanin 2001b). No PEIB, foi coletada apenas na trilha do Cruzeiro para a L ombada, em campo de solo arenoso formando pequena população. 


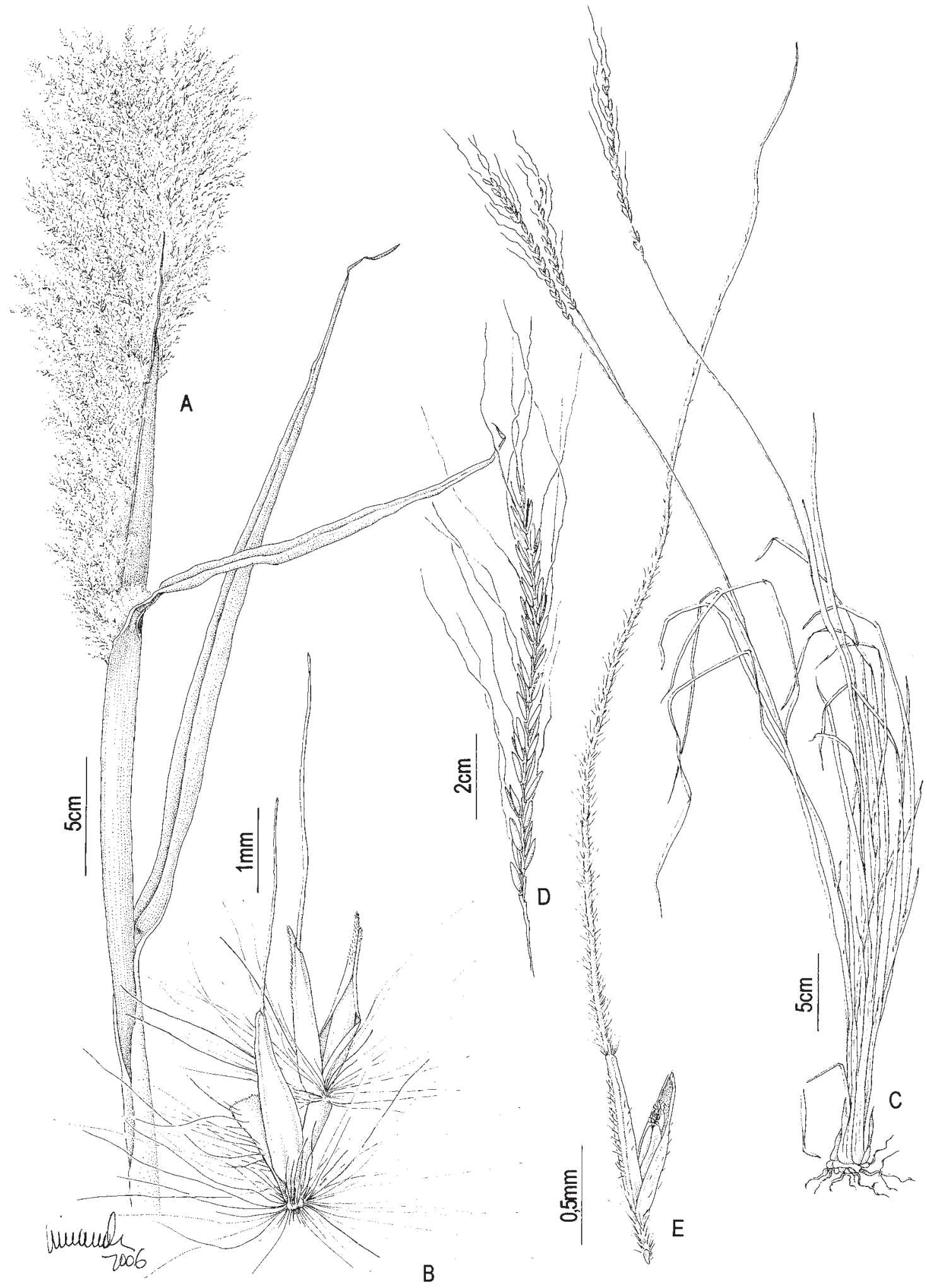

Fig. 2: A-B Saccharum asperum: A . inflorescência; B. par de espiguetas séssil e pedicelada. C-E Trachypogon spicatus: C. hábito; D. ramo florífero; E. espigueta pedicelada (A-B Ferreira 618; C-E Ferreira 579). 


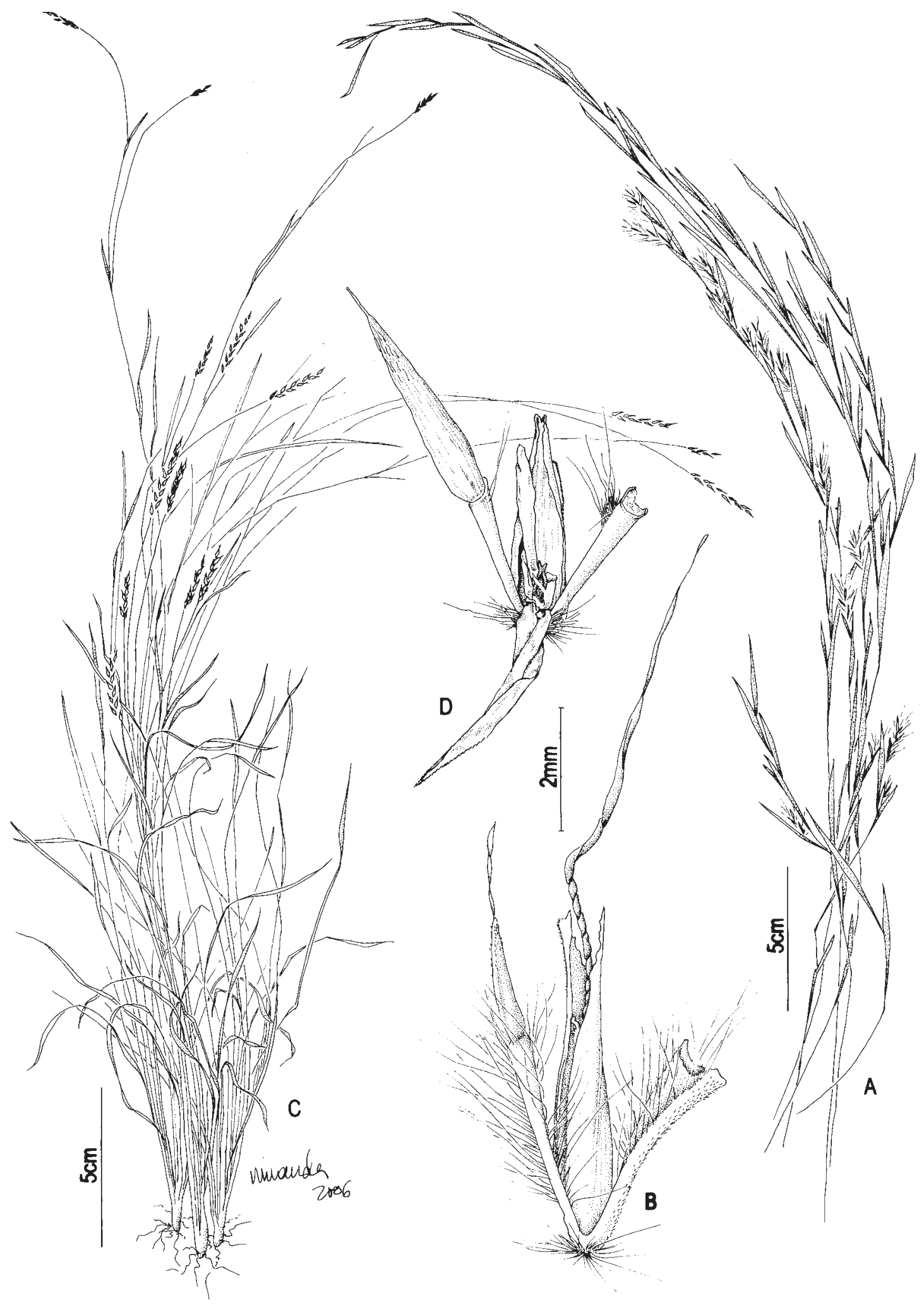

Fig. 3: A -B Schizachyrium condensatum: A. hábito; B. par de espiguetas. C-D S. tenerum: C. hábito; D. par de espiguetas (A-B Dias-M elo 231; C-D Dias-M elo 164). 
8. Schizachyrium tenerum $\mathrm{N}$ ees in $\mathrm{M}$ art. \& Eichl., Fl. bras. enum. pl. 2(1): 336. 1829.

Fig. 3. C-D.

Plantas cespitosas $30-75 \mathrm{~cm}$ alt., geralmente com colmos flácidos. Lígula membranoso-ciliada; lâminas foliares 3-13 x 0,05-0,3 cm, filiformes a lineares, planas ou conduplicadas, glabras em ambas as faces, tricomas marginais de 1-4 $\mathrm{mm}$ na porção basal. Inflorescência $1-11 \mathrm{~cm}$ compr., ramos floríferos eretos na maturidade, solitários ou 2-5, terminais, parcialmente incluídos ou totalmente exsertos da espatéola; entrenós da ráquis e pedicelos retos na maturidade, entrenós da ráquis pilosos na base, pedicelos pilosos na porção superior de uma das margens. E spiguetas sésseis 4-6 mm compr.,bissexuadas, aristas 4-7 mm compr.; gluma inferior convexa, glabra ou escabérula; espiguetas pediceladas 3-5 mm compr., desenvolvidas, neutras, glabras ou escabérulas, múticas ou aristadas. C ariopse não observada.

Material examinado: 8.VII.1990, R.C. Oliveira s.n. (CES) 25202, RB); 19.VI.1991, R.C. Oliveira et al. 18 (CEN n.v., CESJ); 3.II.1993, R.C. Oliveira 136 (BHCB, CESJ); XII.1998, L.G. Rodela Q9-190 (CES) ); 30.III.2004, R. Dias-M elo et al. 164 (K, RB); 30.III.2004, R. Dias-M elo et al. 171 (CEPEC, K, M BM, RB, SP).

Distribuição geográfica e habitat: ocorre do sul dos Estados U nidos até a A rgentina em penhascos rochosos e declividades com cobertura graminosa e locais quentes (Türpe 1984). No Brasil, através dos dados de herbário, verificouse a ocorrência desta espécie no $M$ aranhão, Bahia, Distrito Federal, Goiás, M inas Gerais, São Paulo e Rio Grande do Sul, em campo graminoso, campo rupestre e borda de mata semidecídua. No PEIB, ocorre de forma esparsa no campo rupestre entre fendas de rochas e em solo arenoso, sempre em local ensolarado.

Trachypogon Nees in M art. \& Eichl., Fl. bras. enum. pl. 2(1): 341. 1829.

Trachypogon é um gênero que apresenta grande variabilidade morfológica entre as populações, o que dificulta um consenso entre os autores em relação à sua taxonomia (e.g. Renvoize 1984, Clayton \& Renvoize 1986, J udzi ewicz 1990, Flores 2001). Compreende aproximadamente 15 espécies distribuídas em ambientes campestres da Á frica e A méricas (Flores 2001). N o neotrópico ocorrem três espécies (Zuloaga et al. 2003), das quais uma foi registrada no PEIB.

9. Trachypogon spicatus (L . f.) K untze, Revis. Gen. Pl. 2: 794.1891.

Fig. 2. C-E.

Plantas perenes, 0,45-1 m alt., cespitosas; nós portando um anel de tricomas seríceos. Bainhas foliares pubescentes; lígula membranosa; lâminas foliares 5-25 x 0,1-0,5 cm, lineares, planas ou convolutas, pilosas em ambas as faces. Inflorescência com 1-3 ramos floríferos, 5-18 cm compr.; entre- nós da ráquis glabros, nós pilosos e pedicelos esparsamente pilosos. Espiguetas sésseis 5-8 mm compr., múticas, masculinas, pilosas; espiguetas pediceladas, 6,5-7,2 $\mathrm{mm}$ compr. excluindo o calo agudo e pungente, aristadas, arista 1,6-6 cm compr., bissexuadas, pilosas. Cariopse não observada.

Material selecionado: 22.I.1987, P. Andrade et al. 886, 887 (BHCB); 6.II.1989, L. Krieger S.n. (CESJ 25302); 19.VI.1991, R.C. Oliveira et al. 21 (B HCB, CESJ, M B M ); 20.XII.2003, F.M. Ferreira et al. 579 (CES), RB); 20.XII.2003, F.M. Ferreira et al. 582 (CESJ, RB); 4.II.2004, R. Dias-M elo et al. 142 (K, M BM, RB, SP); 5.II.2004, R. Dias-M elo et al. 157 (CEPEC, K, M BM, RB, SP); 30.III.2004, F. M. Ferreira et al. 677 (K, RB).

Distribuição geográfica e habitat: Trachypogon spicatus ocorre na Á frica e nas A méricas em dunas litorâneas, cerrado e campo rupestre, de 0 a $1.000 \mathrm{~m}$ de altitude (Renvoize 1984). É muito freqüente no Parque podendo inclusive definir a paisagem em al gumas áreas.

Trata-se de uma espécie com ampla variação morfológica e, consequentemente, de difícil circunscrição. A tualmente, há uma tendência em aceitar um conceito mais amplo para a espécie, com vários táxons considerado sinônimos de T. spicatus (Zuloaga et al. 2003).

\section{TRIBO ARUNDINELLEAE}

\section{L oudetiopsis Conert, B ot. Jahrb. Syst. 77: 277. 1957.}

Gênero de distribuição tropical que abriga cerca de 11 espécies encontradas no oeste da Á frica e na A mérica do Sul (Longhi-Wagner 2001a). No PEIB, está representado por uma espécie.

10. L oudetiopsis chrysothrix (N ees) Conert, B ot. J ahrb. Syst. 77: 285. 1957.

Fig. 4. A-D.

Plantas perenes, 0,54-1 m alt., cespitosas. Bainhas foliares pilosas; lígula pilosa; lâminas foliares $12-37 \times 0,1$ $0,4 \mathrm{~cm}$, convolutas, raramente planas ou conduplicadas, face abaxial glabra, face adaxial pilosa ou glabrescentes, com tricomas longos e sedosos. Inflorescência paniculada, aberta, pauciflora, 7-26 cm compr., ramos comumente secundifloros, pedicelos hirsutos, tricomas dourados. E spiguetas 12-16 mm compr., excluindo aristas, subsésseis, em grupos de (2) 3 dando a impressão de uma só espigueta longo-pedicelada; glumas agudas, a inferior 9-11 mm compr., hirsutas, tricomas dourados de base tuberculada e castanha, a superior 14-16 mm compr., glabra ou com tricomas alvos ou dourados esparsos; antécio inferior neutro ou masculino; lema inferior 13-14 mm compr., membranoso, glabro, mútico; antécio superior caduco na maturação; lema superior 6-8 $\mathrm{mm}$ compr., cartáceo, com tricomas sedosos e alvos, ápice bífido, dentes 1-2 mm compr., entre os quais se origina uma arista reta ou geniculada de 4,5-7 cm compr., composta pela coluna, dourada, desenvolvida e helicoidal, pela súbula, reta 


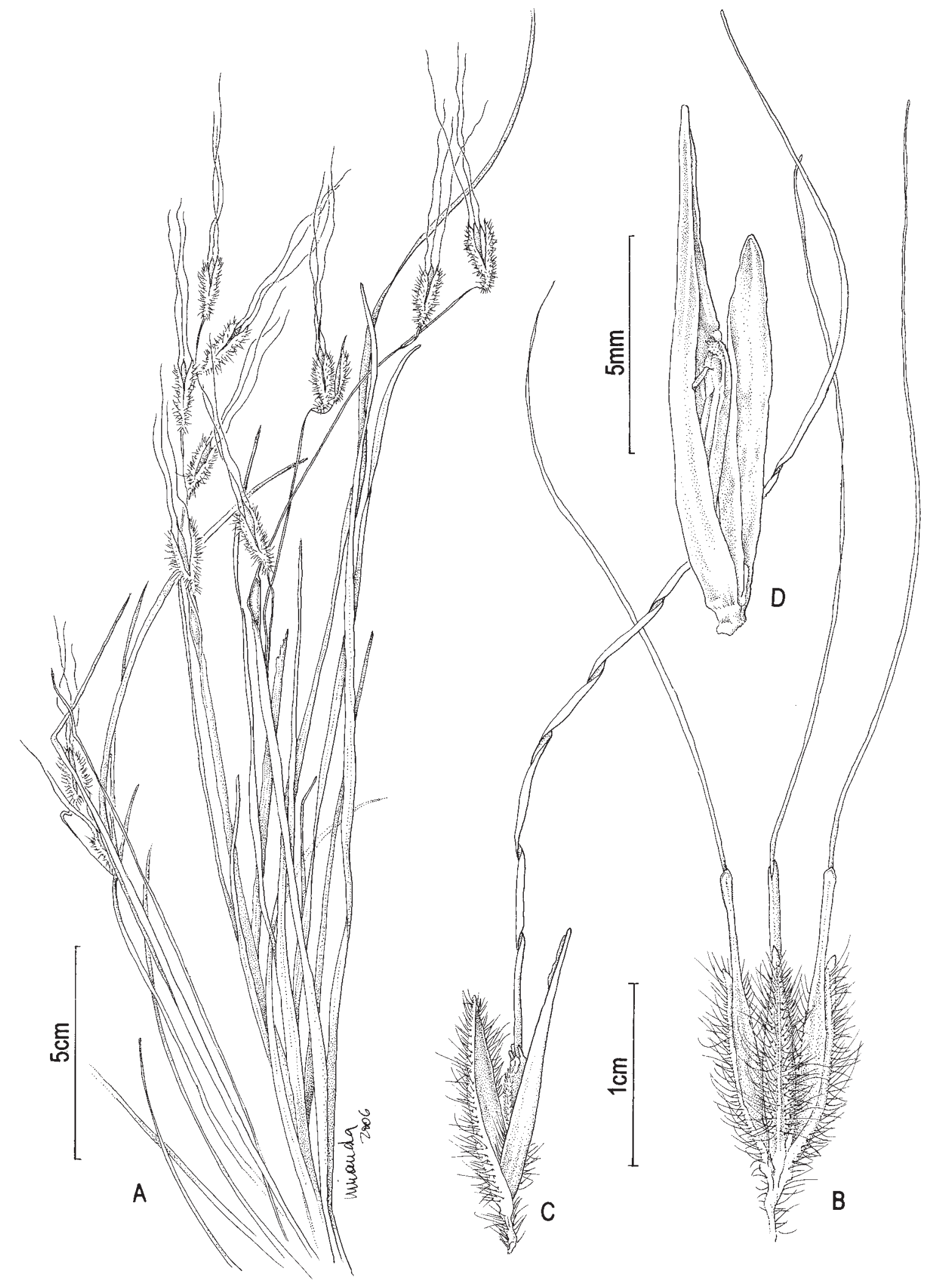

Fig. 4: A-D Loudetiopsis chrysothrix A. hábito; B. tríade de espiguetas; C. espigueta isolada; D. antécio inferior com flor masculina. (A -B Medeiros 356; C-D Dias-M elo 140). 
e estramínea, e pelo calo 0,5-1,2 mm compr., piloso, truncado, bífido ou oblíquo, sendo as aristas caducas na maturação. C ariopse não observada.

Material selecionado: 21.I.1987, P. Andrade et al. 884 (BHCB); 5.XII.1992, R.C. Oliveira 101 (CES), RB); 6.II.1996, L.G. Rodela RQ1-2 (CESJ); 18.X.2003, R. Dias-M elo et al. 10 (RB); 4.II.2004, R. Dias-M elo et al. 140 (K, RB, SP).

Distribuição geográfica e habitat: Loudetiopsis chrysothrix ocorre no B rasil Central, M inas Gerais e São Paulo, em cerrado e campo rupestre (L onghi-Wagner 2001a, LonghiWagner \& Todeschini 2004). A través dos dados de herbário foi possível verificar também, sua ocorrência nos campos rupestres da B ahia (Fonseca et al. 2796 (SP)). No PEIB, ocorre nos campos rupestres nas áreas mais baixas, onde forma grandes populações.

\section{TRIBO PANICEAE}

Axonopus P. B eauv., Ess. A grostogr. 12. 1812.

Gênero com cerca de 110 espécies, nativo dos trópicos e subtrópicos das A méricas, com al guns representantes introduzidos no Velho M undo (Clayton \& Renvoize 1986). No PEIB Axonopus está representado por sete espécies.

M uitas das espécies hoje posicionadas em Axonopus foram descritas em Paspalum. Outro gênero facilmente confundido com Axonopus é Digitaria. Porém, Axonopus difere destes, respectivamente, na posição das espiguetas, as quais apresentam o dorso da gluma superior e do lema superior oposto a ráquis e a presença de espiguetas solitárias em cada nó da ráquis (Giral do-Cañas 2001). A inflorescência e os caracteres vegetativos são notavel mente uniformes, o que torna o gênero facilmente reconhecível, porém dificulta a taxonomia interna, já que as diferenças entre muitas das espécies são tênues (Clayton \& Renvoize 1986).

11. Axonopus aureus P. Beauv., Ess. Agrostogr. 12. 1812.

Fig. 5. A-C.

Plantas perenes, $56-80 \mathrm{~cm}$ alt., cespitosas, às vezes levemente decumbentes; nós glabros. Bainhas foliares glabras ou pilosas na margem; lígula membranoso-ciliada; prefoliação convoluta; lâminas foliares $3-8 \times 0,08-0,2 \mathrm{~cm}$, lineares ou linear-lanceoladas, glabras ou glabrescentes, ápice agudo, margem ciliada ou portando tricomas tuberculados de ca. $5 \mathrm{~mm}$ compr. Inflorescência com 2-4 ramos unilaterais espiciformes, subdigitados, 2,5-6 cm compr.; ráquis setosa, margem portando tricomas tuberculados, Iongos, castanhodourados, no ápice dos pedicel os tais tricomas também estão presentes formando tufos sob as espiguetas. E spiguetas 1,2$1,5 \times 0,7-0,9 \mathrm{~mm}$, elípticas; gluma inferior ausente; gluma superior 1,2-1,5 x 0,7-0,9 mm, 2-nervada, nervuras pouco aparentes, nervura central ausente, ápice obtuso, com tricomas curtos que caducam com a maturidade; lema inferior
1,2-1,5 x 0,7-0,9 mm, 2-nervado, nervura pouco aparente, nervura central ausente, ápice obtuso, com tricomas curtos que caducam com a maturidade; antécio superior 1,2-1,5 $\mathrm{x}$ 0,7-0,9 mm, levemente papiloso, glabro, castanho, brilhoso, coriáceo. C ariopse não observada.

Material examinado: 3.II.1993, R.C. Oliveira 144 (CES), RB); 30.III.2004, R. Dias-M elo et al. 161 (K, RB ); 18.III.2005, R. Dias-M el 0 et al. 244 (K, RB).

Distribuição geográfica e habitat: ocorre desde a A mérica Central e Antilhas ao sul do Brasil, em cerrado, campo, campo rupestre e restinga (Renvoize 1984, Judziewicz 1990, Valls et al. 2001, L onghi-Wagner \& Todeschini 2004). No PEIB, é freqüente e forma grandes populações em solo areno-argiloso ou argiloso, ao sol ou em áreas sombreadas por candeia (E remanthus erythropappus (DC.) MacL eish).

Giraldo-Cañas (2001) relata que Axonopus aureus é uma espécie muito variável, tanto em seus caracteres vegetativos quanto nos reprodutivos, o que torna sua circunscrição bastante complexa. Pode ser confundido com A. chrysoblepharis ( L ag.) C hase, porém, essa espécie apresenta tricomas fortemente tuberculados nas margens das lâminas foliares, 0 que não ocorre em A. aureus (Valls et al. 2001).

12. Axonopus brasiliensis (Spreng.) Kuhlm., Comm. Lin. Telegr., B ot. 67(11): 47. 1922.

Fig. 5. D.

Plantas perenes, 60-65 cm alt., cespitosas; nós glabros. Bainhas foliares tornando-se fibrosas junto à base da planta quando vel has, glabras, margem ciliada; lígula membranoso-ciliada; prefoliação convoluta; lâminas foliares 13-22 x 0,05-0,1 cm, lineares, convolutas, glabras, ápice obtuso ou subagudo, margem com tricomas tuberculados. Inflorescência com 2-3(-4) ramos unilaterais espiciformes, digitados ou subdigitados, 6,5-10,3 cm compr.; ráquis com tricomas tuberculados, longos e alvos na margem. Espiguetas 3,5-4 x 0,9-1,2 mm, estreitamente elípticas a lanceoladas; gluma inferior ausente; gluma superior 3,5-4 x 0,9-1,2 mm, 5-nerva$\mathrm{da}$, tricomas tuberculados, longos e alvos ao longo das nervuras, nervuras salientes, ápice agudo; lema inferior estéril, 3,5-4 x 0,9-1,2 mm, 3-4-nervado, com tricomas tuberculados, longos e al vos ao longo das nervuras, nervuras sal ientes, ápice agudo; antécio superior frutífero 3,5-4 × 0,9-1,2 mm, castanho-claro a castanho-escuro, coriáceo; lema superior glabro, ápice pubérulo; pálea superior levemente papilosa, portando curtos tricomas no ápice. C ariopse não observada.

M aterial examinado: 29.VI.1991, F.R. Salimena s.n. (CESJ 25468); 5.XII.1992, R.C. Oliveira 98 (CES) ); 20.XII.2003, F.M. Ferreira et al. 604 (CES), RB); 16.III.2005, R. Dias-M elo et al. 223 (K, RB).

Distribuição geográfica e habitat: A. brasiliensis ocorre desde os estado do A mazonas até o Paraná e porção oriental da B olívia, crescendo em áreas abertas de serras, em savanas de areias brancas, em campinas e nos afloramentos rocho- 
sos do Escudo Brasileiro, entre 100 e $1.300 \mathrm{~m}$ de altitude (Giraldo-Cañas 2001). No PEIB, é encontrada no campo rupestre entre populações de Loudetiopsis chrysothrix, em solo arenoso, em solo rico em húmus ou menos freqüentemente em solo argiloso.

13. Axonopus complanatus ( $\mathrm{N}$ ees) Dedecca, B ragantia 15: 265. 1956.

Fig. 5. E.

Plantas anuais, 10-17 cm alt., não cespitosas, estoloníferas; nós glabros a pilosos. Bainhas foliares glabras a pilosas, margem lisa; lígula membranoso-ciliada; prefoliação conduplicada; lâminas foliares 1,2-4 x 1,5-3,5 cm, conduplicadas ou planas, glabras em ambas as faces, ápice obtuso, assimétrico e retuso, margem no ápice escabra e na base esparsamente coberta por tricomas finos, de base tuberculada. Inflorescência com 2-3 ramos unilaterais espiciformes, verticilados ou subverticilados, conjugados a subconjugados, 2-4 cm compr., inflorescências axilares presentes; ráquis glabra, escabérula na margem, terminando em uma espigueta. E spiguetas 2-2,3 x 0,7-0,8 mm, oval-lanceoladas; gluma inferior ausente; gluma superior 2-2,3 x 0,7-0,8 mm, 4-nervada, sem nervura central evidente, ápice agudo, simétrico, com esparsos tricomas próximos às nervuras e na base, escabérula em direção ao ápice, membranácea a hialina, verde-estramínea com máculas vináceas, paleácea; antécio inferior neutro; lema inferior 2-2,1 x 0,7-0,8 mm, 2-4-nervado, sem nervura central evidente, ápice agudo, subglabro, membranáceo a hialino, verde-estramíneo com máculas vináceas; pálea inferior ausente; antécio superior frutífero; lema superior 2-2,1 x 0,7-0,8 mm, liso, coriáceo, ápice agudo, com curtos tricomas. C ariopse não observada.

Material examinado: 30.III.2004, R. Dias-M elo et al. 172 (K, RB).

Distribuição geográfica e habitat: espécie exclusiva do B rasil, onde ocorre nas Regiões Nordeste, Centro-Oeste e Sudeste (Valls et al. 2001). No PEIB, foram observadas pequenas populações apenas na trilha da Lagoa Seca para a Janela do Céu em solo arenoso.

14. Axonopus fastigiatus (Nees ex Trin.) Kuhlm., Comm. Lin. Telegr., B ot. 67(11): 87. 1922.

Fig. 5. F.

Plantas perenes, $16-28 \mathrm{~cm}$ alt., cespitosas; base freqüentemente bulbosa; nós glabros. Bainhas foliares curtamente pilosas; lígula pilosa; prefoliação convoluta; lâminas foliares 2-7 x 0,07-0,2 cm, lineares, planas ou conduplicadas, face abaxial pilosa, face adaxial pilosa a glabrescente, ápice agudo. Inflorescência com 2-3 ramos unilaterais espiciformes, conjugados, 3,5-6 cm compr.; ráquis glabra ou escabérula. E spiguetas 2,5-3,5 x 0,6-0,9 mm, estreitamente elípticas a oblongas; gluma inferior ausente; gluma superior 2,5-3,5 x 0,6-0,9 mm, 2(-3)-nervada, margem ciliada com tricomas pectinados, membranácea, lema inferior, 2(-3)-nervado, margem ciliada com tricomas pectinados a subglabra, membranáceo; pálea inferior ausente; antécio superior 2,5-3,5 x 0,6-0,9 mm, pubérulo, portando um tufo de tricomas, estramíneo, ápice agudo. C ariopse não observada.

Material selecionado: 12.V.1970, L. Krieger S.n. (CESJ 8565, RB); 27.IV.1988, P. Andrade 1176 (BHCB); XII.1998, L.G. Rodela Qd-2 (CESJ); 24.III.2001, M.A. Heluey et al. 81 (CESJ); 24.III.2001, M.A. Heluey et al. 92 (CES) ); 30.III.2004, R. D ias-M elo et al. 177 (K, M BM, RB, SP); 17.III.2005, R. Dias-M elo et al. 232 (K, RB, SP).

Distribuição geográfica e habitat: A. fastigiatus ocorre nos campos rupestres da Bahia, Goiás e M inas Gerais (Renvoize 1984; Longhi-Wagner \& Todeschini 2004). É comumente encontrada nas partes altas do Parque, como nas proximidades do Cruzeiro, na L ombada e J anela do Céu, no campo rupestre ou em campos encharcáveis.

15. Axonopus fissifolius (Raddi) Kuhlm., Comm. Lin. Telegr., B ot. 67(11): 87. 1922.

Fig. 5. G.

Plantas perenes, 5-8 cm alt., estoloníferas; nós glabros. Bainhas foliares glabras, pilosas na margem próxima à região ligular; lígula membranoso-ciliada; prefoliação conduplicada; lâminas foliares 2-4 x 0,1-0,2 cm, planas ou conduplicadas, glabras em ambas as faces, ápice obtuso e assimétrico ou retuso, bífido nas planas, escabérulas na margem e no ápice. Inflorescência com 2-3 ramos unilaterais espiciformes, conjugados, verticilados, 2-3,5 cm compr., axilas com tricomas curtos, inflorescências axilares presentes; ráquis glabra, escabérula na margem, terminando em uma espigueta. E spiguetas 1,7-2 $\times$ 0,4-0,7 mm, oblongas a estreitamente oblongo-lanceoladas; gluma inferior ausente; gluma superior 1,7-2 $\times$ 0,4-0,7 mm, 4-nervada, sem nervura central evidente, ápice apiculado, pilosa na margem e ao longo das nervuras, base comosa; antécio inferior neutro; lema inferior 1,7-1,9 x 0,4-0,7 mm, 2-nervado, sem nervura central evidente, ápice apiculado, pilosidade semelhante à da gluma superior; pálea inferior ausente; antécio superior frutífero; lema superior glabro, liso, ápice papiloso. C ariopse não observada.

M aterial selecionado: 5.V III.1993, R. C. Oliveira 206 (CESI, RB); 19.XII.2003, F. M. Ferreira 566 (CES), RB); 17.III.2005, R. Dias-M elo 238 (HUEFS, RB, SPF).

Distribuição geográfica e habitat: ocorre desde os Estados U nidos até a A rgentina, em cerrados, campos e campos rupestres, em solos pedregosos e, também em locais perturbados, em gramados e em várzeas arenosas (R envoize 1984, Valls et al. 2001). N o PEIB, ocorre principal mente nas partes mais altas como Lombada e Pico do Pião.

16. Axonopus polystachyus G. A. Black, Advancing Frontiers PI. Sci. 5: 62. 1963.

Fig. 6. H. 


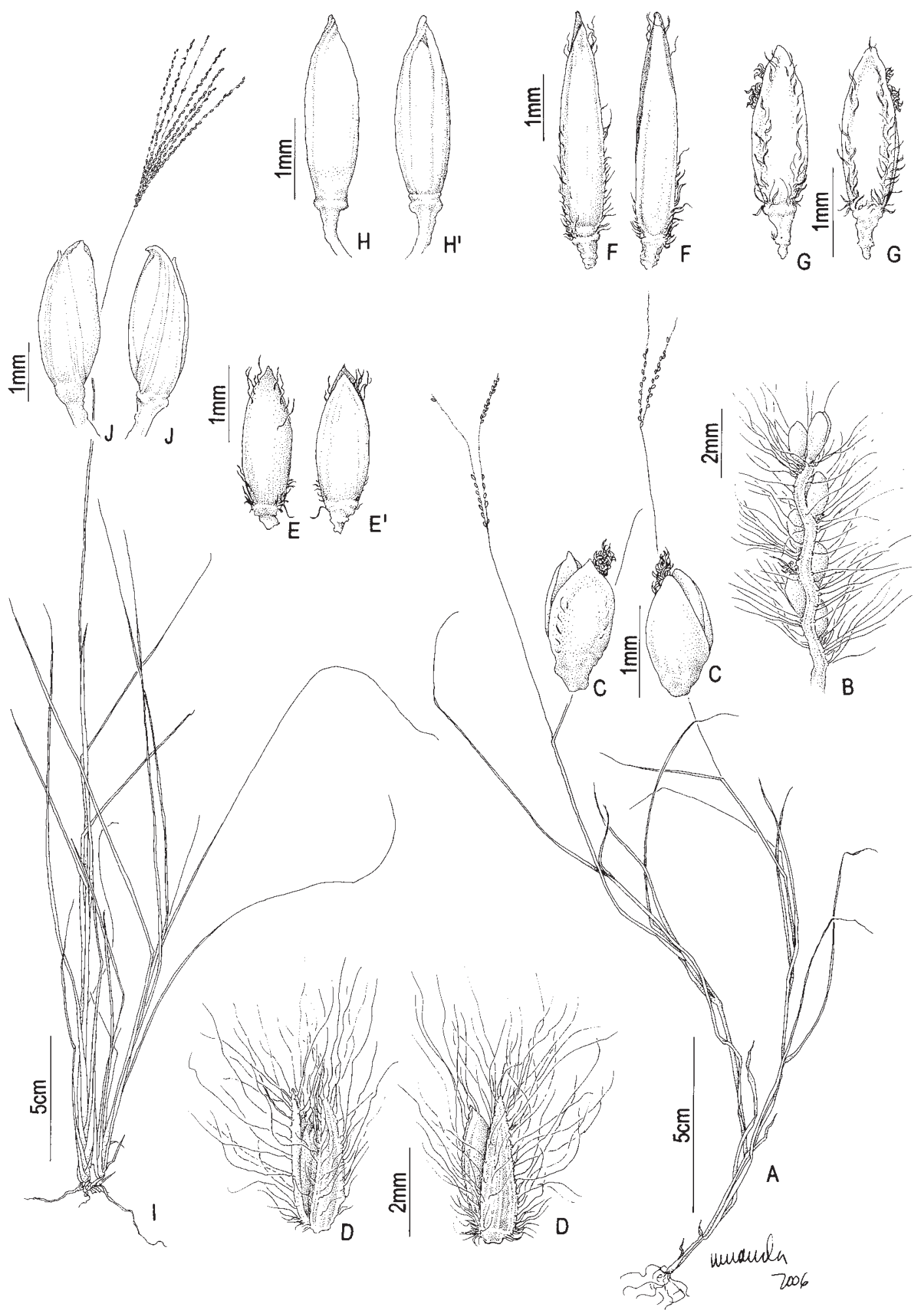

Fig. 5: A-C Axonopus aureus: A. hábito; B. ráquis; C. espigueta vista da gluma superior; C'. espigueta vista do lema inferior. D. A. brasiliensis: espigueta vista do lema inferior; D' espigueta vista da gluma superior. E. A. complanatus: espigueta. F. A. fastigiatus: espigueta vista gluma superior; F' espigueta vista lema inferior. G. A. fissifolius: espigueta vista da gluma superior; G' espigueta vista lema inferior. H. A. polystachyus: espigueta vista da gluma superior; $H^{\prime}$ espigueta vista do lema inferior. I-J A. siccus: I. hábito; J. espigueta vista da gluma superior; J' espigueta vista do lema inferior. (A -C Dias-M elo 244; D Ferreira 604, Dias-M elo 223; E Dias-M elo 172; F Dias-M elo 177; G Oliveira s.n. (CESJ 25529); H Oliveira 31; I-J Ferreira 607). 
Plantas perenes, ca. $83 \mathrm{~cm}$ alt., cespitosas; nós pilosos a glabrescentes. Bainhas foliares glabras, margem escabra; lígula membranoso-ciliada; prefoliação conduplicada; lâminas foliares $5-33$ x 0,2-1,1 cm, planas ou conduplicadas, face adaxial glabra, face abaxial portando tricomas setosos a glabrescente, ápice obtuso e assimétrico, retuso, às vezes acuminado, escabérulo, margem escabra. Inflorescência com 3 ramos unilaterais espiciformes, subconjugados, subverticilados, 10-13 cm compr., inflorescências axilares presentes, axilas seríceas; ráquis glabra, margem escabra, às vezes com tricomas finos e longos próximos aos pedicelos, terminando em uma espigueta. E spiguetas 2,1-2,7 x 0,6-0,8 mm, estreitamente elíptico-lanceoladas; gluma inferior ausente; gluma superior 2,1-2,7 x 0,6-0,8 mm, 4-nervada, sem nervura central evidente, base não comosa, ápice agudo ou apiculado, assimétrico, pilosidade fina e esparsa ao longo das nervuras, hialina; antécio inferior neutro; lema inferior 2,1-2,4 $\mathrm{x}$ 0,6-0,8 mm, 2-4-nervado, subglabro, hialino; pálea inferior ausente; antécio superior frutífero; lema superior 2,1-2,6 x 0,6-0,8 mm, esparsamente papiloso, glabro, membranáceo, ápice subagudo, papiloso. Cariopse não observada.

Material examinado: 20.VI.1991, R.C. Oliveira 31 (CEN n.v., (ESJ, RB).

Distribuição geográfica e habitat: ocorre no Sul e Sudeste do Brasil, em campo cerrado, ao longo de rodovias, em floresta secundária e também em áreas roçadas (Valls et al. 2001). No PEIB, foi coletado próximo a Ponte de Pedra, na margem do Rio do Salto, formando densas touceiras.

17. Axonopus siccus (Nees) Kuhlm., Comm. Lin. Telegr., B ot. 67(11): 87. 1922.

Fig. 5. I-J.

Planta perene, 0,5-1 m alt., cespitosa; nós pilosos. Bainhas foliares glabras ou com pilosidade esparsa, margem inteira, glabra; lígula membranoso-ciliada com cílios longos ou pilosa; prefoliação convoluta; lâminas foliares 7-35 x 0,08$0,3 \mathrm{~cm}$, filiformes, convolutas ou involutas, cilíndricas, raro planas, glabras em ambas as faces, ou escabras na face abaxial e pilosas na adaxial, ápice acuminado e pungente, margem serreada, às vezes com tricomas. Inflorescência com 5-16 ramos unilaterais espiciformes, alternos ou subverticilados, 5-19 cm compr.; ráquis escabra. Espiguetas 1,8-2,5 $x$ 0,6-0,9 mm; gluma inferior ausente, gluma superior 1,82,5 x 0,6-0,9 mm, 5-7-nervado, nervuras evidentes, nervura central evidente, ápice agudo, glabra ou esparsamente pilosa entre as nervuras, tricomas curtos; lema inferior 1,7-2,4 $\mathrm{x}$ 0,6-0,9 mm, 5-7-nervado, nervuras evidentes, nervura central evidente, ápice agudo, glabro ou finamente piloso entre as nervuras, tricomas esparsos e curtos; antécio superior 1,72,3 × 0,6-0,9 mm, glabro, levemente papiloso, subcoriáceo, estramíneo, ápice subagudo. C ariopse não observada.

Material selecionado: 2.XI.1991, R.C. Oliveira S.n. (CES) 32625, RB); 22.II.1992, M. Eiterer S.n. (CESJ 25712); 22.II.1992, M. Eiterer
S.n. (CESJ 25722); 3.II.1993, R.C. Oliveira 138 (CESJ); 8.II.1996, L.G. Rodela Q2-27 (CESJ); 20.X II.2003, F.M. Ferreira et al. 584, 586, 588, 595, 597, 601, 607 (CES), RB); 4.II.2004, R. Dias-M elo et al. 141,144 (K, RB); 20.I.2005, R. C. Forzza et al. 3963 (K, M BM, RB, SP); 17.III.2005, R. Dias-M elo et al. 235a (K, RB); 9.VIII.2005, R. D ias-M elo et al. 295 (RB).

Distribuição geográfica e habitat: Axonopus siccus ocorre na Bolívia, Paraguai, A rgentina, Uruguai e Brasil, em cerrado, em campo seco a úmido, em solo arenoso ou areno-argiloso (Renvoize 1984, Valls et al. 2001). No PEIB, a espécie ocorre em vários locais formando pequenas populações principal mente no campo rupestre, mas também pode ser encontrada em campos encharcáveis, em solo arenoso ou em areia misturada a húmus.

U m aspecto interessante a ser mencionado sobre Axonopus siccus é o registro de plântulas crescendo no interior das espiguetas em uma das populações do Parque (Dias-M elo et al. 295 (RB)). Giraldo-Cañas (2001) registrou a ocorrência de fato semelhante em $A$. aureus e 0 definiu como proliferação vegetativa. 0 autor afirma ainda que este é um fenômeno comum nas espécies perenes de regiões temperadas e ártico-alpinas, onde as mesmas têm um período curto de crescimento. Tal fenômeno pode estar associado à reprodução vegetativa, ser resultado de teratologia ou de variação nos fatores ambientais. Estudos mais aprofundados são necessários para que se possa definir o real mecanismo deste processo, uma vez que proliferação vegetativa ou viviparidade são raros em espécies tropicais, principalmente em Paniceae (Giraldo-Cañas 2001).

Dichanthelium (Hitchc. \& Chase) Gould, B rittonia 26(1): 59. 1974.

A té a década de 1970, D ichanthelium era posicionado em Panicum subgênero Dichanthelium seção Dichanthelium. Gould (1974), com base no dimorfismo foliar e floral, nível de ploidia, síndrome K ranz e ornamentação do antécio superior, eleva o subgênero a categoria genérica. Diversos autores como Pohl (1981), M orrone \& Zuloaga (1991) e Zuloaga et al. (1993) desconsideraram a proposta de Gould (1974) e o mantiveram como subgênero de Panicum. Estudos filogenéticos recentes (Zuloaga et al. 2000, Duvall et al. 2001, Aliscioni et al. 2003) apontam que Panicum é realmente polifilético e a proposta de Gould (1974) de segregação de Dichanthelium é corroborada.

Dichanthelium ocorre nas A méricas e nas A ntilhas em bordas de matas ou em locais abertos, em solos arenosos úmidos ou secos. Para o Neotrópico são referidas 57 espécies (Zuloaga et al. 2003). No PEIB, está representado por apenas uma espécie.

18. Dichanthelium superatum (Hack.) Zuloaga, A mer. J. B ot. 90(5): 817. 2003.

Fig. 6. A-B. 
Planta perene, $50-75 \mathrm{~cm}$ alt., rizomatosa, ereto-decumbente, flexuosa; nós pilosos a glabrescentes. Bainhas foliares pilosas, porém com o envelhecimento da planta a pilosidade permanece apenas na margem; colo piloso; lígula membranoso-ciliada, curtamente membranosa, longamente ciliada; lâminas foliares 5,5-15 x 0,6-1 cm, linear-lanceoladas, planas, ambas as faces pilosas a glabrescentes, ápice agudo e pungente, margem serreada com tricomas estrigosos, base reta. Inflorescência 7-13 x 3-6 cm, panícula aberta, contraída quando jovem. E spiguetas 2,3-3 x 1-1,1 mm, oval-lanceoladas, glabras; gluma inferior 1,6-2 x 0,7-0,9 $\mathrm{mm}$, oval-lanceolada, 3-nervada, nervura central fortemente marcada, ápice agudo, glabra; gluma superior 2-2,3 x 1-1,1 $\mathrm{mm}$, elíptica, 8-nervada, ápice arredondado, glabra; antécio inferior com flor masculina; lema inferior 2-2,5 x 1-1,1 mm, 7-nervado, ápice subagudo; pálea inferior hialina; antécio superior frutífero 2,3-3 x 1-1,1 mm, glabro, lustroso, cartilaginoso, ápice subagudo; lema superior com duas pregas na base. C ariopse não observada.

Material examinado: 2.XI.1991, R.C. Oliveira 35 (BHCB, CESJ); 3.II.1993, R.C. Oliveira 148 (CES), RB); 18.X.2003, R. Dias-M elo et al. 9 (RB); 7.III.2006, F.M. Ferreira et al. 992 (CES), RB).

Distribuição geográfica e habitat: ocorre no Brasil, do Espírito Santo ao Rio Grande do Sul, de 900 a $2.650 \mathrm{~m}$ de altitude (Zuloaga et al. 1993, Zuloaga et al. 2001a). No PEIB, ocorre freqüentemente em beira de mata ciliar e no campo em solo arenoso.

Digitaria Haller, Hist. Stirp. Helv. 2: 244. 1768.

Digitaria possui cerca de 230 espécies distribuídas em regiões tropicais e subtropicais de ambos os hemisférios (Clayton \& Renvoize 1986). No neotrópico, são encontradas 97 espécies (Zuloaga et al. 2003). 0 B rasil é o país das A méricas que possui a maior diversidade do gênero, com 12 espécies exóticas e 26 nativas, das quais nove são endêmicas (Canto-D orow \& L onghi-Wagner 2001). A riqueza específica é praticamente equivalente entre as Regiões Sul, Sudeste, Centro-Oeste e Nordeste, com uma redução na Região N orte. Habitam formações como campos naturais, cerrados, restingas, campos rupestres, sendo comuns em locais alterados (Canto-Dorow \& Longhi-Wagner 2001). No PEIB está representado por quatro espécies. 1802.

19. Digitaria ciliaris (Retz.) Koeler, Descr. Gram. 27.

Fig. 6. C-D.

Planta anual, 20-30 cm alt., decumbente, radicante nos nós inferiores; nós pilosos a glabrescentes. Bainhas foliares pilosas a glabrescentes, tricomas esparsos com base tuberculada; lígula membranosa; prefoliação convoluta; lâminas foliares 2,9-5 x 0,2-0,5 cm, linear-lanceoladas, ambas as faces glabras ou com tricomas tuberculados esparsos, margem serreada. Inflorescência com 2-3 ramos unilaterais espiciformes, subverticilados a verticilados, 4-7 cm compr., axilas pubérulas; ráquis 0,2-0,5 mm larg., margem escabra, terminando em uma espigueta. E spiguetas binadas, lanceoladas, pubescentes, tricomas seríceos presentes na gluma superior e lema inferior; gluma inferior 0,3-0,5 mm compr., ápice agudo; gluma superior 1,6-1,8 × 0,4-0,6 mm, ápice agudo, 3-5-nervada, pilosa em toda sua extensão; antécio inferior neutro; lema inferior 2,8-3 x 0,7-1 mm, 5-7-nervado, ápice agudo, piloso na margem; pálea inferior ausente; antécio superior frutífero 2,7-2,9 × 0,7-1 mm, papiloso, castanho escuro na maturação, membranáceo, lema superior sem nervura aparente. C ariopse não vista.

M aterial examinado: 19.XII.2003, F.M. Ferreira et al. 567 (CES), RB); 6.III.2006, F.M. Ferreira et al. 954 (CESJ, RB).

Distribuição geográfica e habitat: ocorre nos trópicos e subtrópicos. No Brasil, distribui-se amplamente em locais al terados de campo e cerrado, bem como beira de estradas e caminhos (R envoize 1984, Canto-D orow 2001). Considerada uma erva daninha pantropical, é invasora comum de lavouras de verão como soja, milho e arroz (Judziewicz 1990, Boldrini et al. 2005). No PEIB, foi encontrada em borda de mata na trilha entre a casa do pesquisador e o centro de informação. A ocorrência de D. ciliaris neste local pode ser atribuída ao fato do local ser de intensa passagem de pedestres e veículos.

20. Digitaria corynotricha (Hack.) Henrard, M eded. Rijks-Herb. 61: 2. 1930.

Fig. 6. E.

Planta perene, ca. $70 \mathrm{~cm}$ alt., cespitosa; nós glabros a subglabros. Bainhas foliares glabras, portando tricomas na margem principalmente em direção ao ápice, tornando-se fibrosas na maturidade da planta; lígula membranosa; prefoliação convoluta; lâminas foliares $11-27 \times 0,4-0,6 \mathrm{~cm}$, linear-lanceoladas, planas, face abaxial escabra, ou ambas as faces portando finos e esparsos tricomas, que aumentam de concentração em direção à região ligular, margem intei ra, lisa. Inflorescência com 2-4 ramos unilaterais espiciformes, subdigitados, 2-10 cm compr., axilas glabras; ráquis 0,4-0,7 $\mathrm{mm}$ larg., margem escabra, terminando em uma espigueta. Espiguetas em grupos de 2-5, elíptico-lanceoladas, com tricomas claviformes entre as nervuras, estramíneos a castanhos-escuros, curtos e adpressos à gluma superior e lema inferior; gluma inferior 0,1-0,2 mm compr.; gluma superior 1-2 x 0,5-1 mm, 3-5-nervada, ápice obtuso a subagudo, membranácea; antécio inferior neutro; lema inferior 1,8-2 $x$ 0,9-1,1 mm, 5-7-nervado, ápice obtuso, membranáceo; pálea inferior ausente; antécio superior frutífero 1,9-2,1 x 0,9-1,1 $\mathrm{mm}$, sem nervuras aparentes, papiloso, castanho-escuro a nigrescente na maturação, coriáceo, ápice apiculado. C ariopse não observada. 
Material examinado: 6.III.2006, F.M . Ferreira et al. 951 (CES), RB).

Distribuição geográfica e habitat: ocorre no Brasil e Paraguai, em cerrado ou campo seco (Renvoize 1984). No PEIB, ocorre na trilha entre a casa do pesquisador e o centro de informações, em borda de mata.

Digitaria corynotricha é uma espécie de fácil reconhecimento devido aos seus tricomas claviformes, que se assemeIham a pequenos grãos de areia grudados na superfície das espiguetas.

21. Digitaria fuscescens (J. Presl) Henrard, Meded. Rijks-Herb. 61: 8. 1930.

Fig. 6. F.

Plantas perenes, 9-25 cm alt., estoloníferas; nós glabros. Bainhas foliares glabras, margem lisa, membranosa, al guns espécimes apresentam bainhas velhas fibrosas; lígula membranosa; prefoliação convoluta; lâminas foliares 1,3-3,6 x 0,27-0,4 cm, oval-lanceoladas, glabras, apenas com poucos tricomas próximo à região ligular, margem escabérula. Inflorescência com 2-3 ramos unilaterais espiciformes, verticilados, conjugados ou subconjugados, 2-5,5 cm compr., axila, pubérula; ráquis 0,4-0,6 $\mathrm{mm}$ larg., margem escabérula, terminando em uma espigueta. E spiguetas em grupos de (2-) 3, elíptico-lanceoladas, pubescentes; gluma inferior ausente; gluma superior 1,1-1,3 x 0,4-0,6 mm, 3-nervada, ápice obtuso, portando tricomas seríceos entre as nervuras; antécio inferior neutro; lema inferior 1,2-1,6 x 0,4-0,6 mm, 5-7-nervado, ápice obtuso, pubérulo, tricomas curtos e finos entre as nervuras; pálea ausente; antécio superior frutífero 1,2-1,7 x 0,4-0,6 mm, levemente papiloso, castanho-claro a castanhoescuro na maturação, coriáceo, ápice agudo. Cariopse não observada.

Material examinado: 19.X II.2003, F.M . Ferreira et al. 565 (CES), RB); 6.III.2006, F.M. Ferreira et al. 952 (CESJ, RB).

Distribuição geográfica e habitat: espécie do sudeste da Á sia introduzida nos trópicos onde ocorre em cerrado, restinga e locais alterados, entre 0 e $1.000 \mathrm{~m}$ de altitude (Renvoize 1984). Digitaria fuscescens é nativa das ilhas do Oceano Índico e sudoeste do Pacífico, provavelmente introduzida na A mérica do Sul e amplamente distribuída por quase todo o B rasil (Canto-D orow 2001). No PEIB, foi coletada ao lado da casa do pesquisador e em borda de mata na trilha entre a casa do pesquisador e o centro de informação. A ssim como D. ciliaris, esta espécie foi coletada no local do PEIB onde a movimentação de pedestres e veículos é mais intensa.

22. Digitaria horizontalis Willd., Enum. PI. 92. 1809. Fig. 6. G-H.

Plantas anuais, 68-90 cm alt., decumbentes, não radicantes nos nós inferiores. Bainhas foliares pilosas a glabras, quando pilosas apresentam tricomas de base tuberculada, não se tornando fibrosas com a maturidade; nós glabros; lígula membranosa; lâminas foliares 3-42 x 0,5-1,2 cm, linear-lanceoladas, ambas as faces glabras a pilosas, tricomas de base não tuberculada, caducos com a maturidade, ápice agudo, margem escabérula. Inflorescência com 4-22 ramos unilaterais espiciformes, subverticilados a verticilados de 5-15 cm compr., axilas pubérulas, portando alguns poucos tricomas longos; ráquis 0,3-0,5 mm larg., margem escabra, terminando em uma espigueta. E spiguetas binadas, lanceoladas, pubescentes, tricomas seríceos, presentes nas glumas superiores e lemas inferiores; gluma inferior ausente; gluma superior 1,6-2 x 0,4-0,5 mm larg., 3-nervada, ápice obtuso a subagudo; antécio inferior neutro; lema inferior 2,3-2,5 $\mathrm{x}$ 0,7-1,5 mm, 5-7-nervado, ápice agudo, glabro ao longo da nervura central, piloso apenas nas nervuras laterais e na margem; pálea inferior ausente; antécio superior frutífero 2,22,4 x 0,7-1,5 mm, glabro, escabérulo no ápice, levemente rugoso transversal mente, castanho-claro na maturação, lema superior com nervura central marcada no ápice. Cariopse não observada.

M aterial examinado: 17.III.2005, R. D ias-M elo et al. 235b (K, RB).

Distribuição geográfica e habitat: espécie freqüente em regiões tropicais de ambos os hemisférios, ocorrendo na A mérica do Sul desde as Guianas até a Bolívia, Paraguai e A rgentina, e é amplamente distribuída em quase todo o B rasil (Canto-Dorow 2001). É uma espécie daninha que ocorre em cerrados, áreas alteradas, sendo também invasora de cafezais e cultivos de pinheiros (Canto-Dorow 2001). No PEIB, foi coletada na beira de trilha nas proximidades da gruta dos Três A rcos, local de intensa visitação, em local ensolarado e sobre solo arenoso.

E chinolaena Desv., J. B ot. A gric. 1: 75. 1813.

Gênero com oito espécies que ocorrem em savanas, duas em M adagascar e seis na A mérica do Sul (Clayton \& Renvoize 1986, Judziewicz 1990). No PEIB, está representado por uma espécie.

23. E chinolaena inflexa (Poir.) Chase, Proc. Biol. Soc. Wash. 24: 117. 1911.

Fig. 7. A.

Plantas anuais, 50-65 cm alt., cespitosas, radicantes nos nós inferiores; nós glabrescentes. Bainhas foliares glabras, margem ciliada, colo piloso ou glabro; lígula ciliada; lâminas foliares 2,5-7 × 0,2-0,5 cm, lanceoladas ou linearlanceoladas, face adaxial glabra, face abaxial pilosa a gabrescente, ápice agudo ou acuminado, margem serreada as vezes portando tricomas tuberculados, base subcordada, tuberculado-pilosas. Inflorescências 2,5-4 cm compr., ramo solitário, unilateral espiciforme, reflexo, divergente; ráquis 0,8-1 mm larg., hirsuta em toda sua extensão, margem com tricomas tuberculados. E spiguetas 6-12 x 0,8-2,5 mm, elíp- 


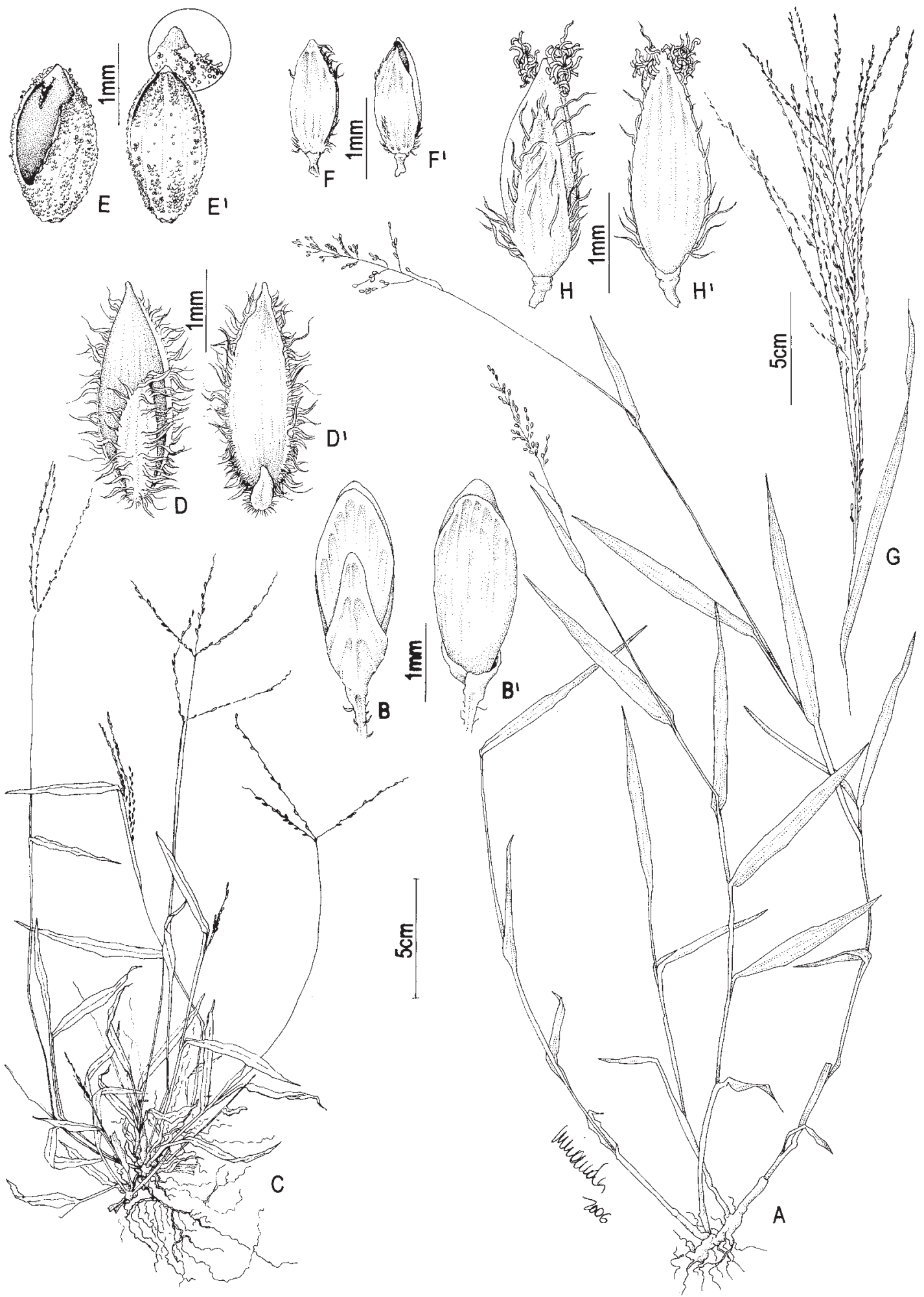

Fig. 6: A-B Dichanthelium superatum: A. hábito; B. espigueta vista da gluma inferior; B'. espigueta vista da gluma superior. C-D Digitaria ciliaris: C. hábito; D. espigueta vista da gluma superior; D'. espigueta vista gluma inferior. E D. corynotricha: espigueta com parte do lema inferior removido para evidenciar o antécio superior; E' espigueta vista do lema inferior evidenciando os tricomas claviformes (detal he) . F D. fuscescens: espigueta vista da gluma inferior; $F^{\prime}$. espigueta vista da gluma superior. G-H D. horizontalis: G. inflorescência; H. espigueta vista da gluma inferior; H'. espigueta vista da gluma superior. (A -B Ferreira 992, C-D Ferreira 954, E Ferreira 951, F Ferreira 565, G-H Dias-M elo 235b). 
tico-lanceoladas, alternadas; gluma inferior 6-12 x 0,8-2,5 mm, 7-9-nervada, com tricomas híspido-tuberculados, coriácea, acuminada, margem membranácea; gluma superior 4-10 x 0,8-2 mm, 5-7-nervada, acuminada, portando de maneira esparsa tricomas hirtos em toda sua extensão, os do ápice mais longos, alguns tuberculados; antécio inferior neutro ou masculino; lema inferior ca. $5 \mathrm{~mm}$ compr., 5-nervado, agudo, subcoriáceo; pálea inferior ca. $5 \mathrm{~mm}$ compr., aguda, portando em sua base vestígio de lodículas; antécio superior ca. $4 \mathrm{~mm}$ compr., coriáceo, brilhoso, pardacento, portando dois apêndices aliformes laterais na base da região ventral; anteras alvas e estigmas amarel os. C ariopse não observada.

Material selecionado: 14.V.1970, L. Krieger s.n. (BHCB, CES) 8543, ESA n.v., MBM n.v.); 6.IV.1987, P. Andrade et al. 959 (B HCB); 31.III.2004, R.C. Forzza et al. 3297 (RB ); 16.III.2005, R. D ias-M elo et al. 204 (K, RB).

Distribuição geográfica e habitat: E. inflexa ocorre na Colômbia, Venezuela, Guianas e Brasil, onde tem como limite sul de distribuição o estado de São Paulo, sempre relacionado a cerrado ou campos (Renvoize 1984, Judziewicz 1990, Santos \& Sano 2001a). No PEIB, ocorre no campo rupestre e campo rupestre arbustivo, em solo arenoso, onde forma grandes populações.

H omolepis Chase, Proc. Biol. Soc. Wash. 24: 146. 1911.

Gênero comumente confundido com Panicum, porém, a combinação de longas glumas, espigueta lanceolada e lema superior estreito nunca ocorre em Panicum. A brange cinco espécies que habitam bordas de mata ou campos desde o M éxico, A ntil has até a A rgentina (J udzi ewicz 1990). No PEIB, está representado por uma espécie.

24. Homolepis glutinosa (Sw.) Zuloaga \& Soderstr., Smithsonian Contr. B ot. 59: 19. 1985.

Fig. 7. B-C.

Plantas perenes 0,7-1,2 $\mathrm{m}$ alt., decumbentes, radicantes nos nós inferiores; nós glabros. Bainhas foliares híspidas, margem ciliada; colo piloso; lígula membranoso-ciliada, curtamente ciliada; lâminas foliares $9-29 \times 1-2 \mathrm{~cm}$, lanceoladas, base da lâmina portando tricomas próximos à região ligular, ambas as faces escabras, ápice agudo, margem escabra, sutilmente atenuadas em direção à base. Inflorescência 15-24 x 4-19 cm, panícula típica, laxa; ramos verticilados na base e alternos ou opostos no ápice. E spiguetas 2,5-3,5 $x$ 1,2-2 mm, obovais ou elípticas, glabras, viscosas; gluma inferior 2,2-3,0 x 1,2-2 mm, 5-nervada, subaguda ate apiculada; gluma superior 2,2-2,7 x 1,2-2 mm, 7-nervada, truncada a obtusa; antécio inferior neutro, lema inferior 2,2-3 $x$ 1,2-2 mm, 4-5-nervado, agudo; pálea inferior ca. $2 \times 0,5 \mathrm{~mm}$, lanceolada, pal eácea; antécio superior 2,5-3,5 x 1,2-1,5 mm, estreitamente elíptico, brilhoso, portando tricomas diminutos no ápice. C ariopse não observada.
Material examinado: 30.III.2004, R. Dias-M elo et al. 170 (K, $M B M, R B, S P)$.

Distribuição geográfica e habitat: ocorre desde o M éxico e A ntilhas até a A rgentina, em bordas de mata ou clareiras, campos e restingas, de 0 a $2.500 \mathrm{~m}$ de altitude (J udziewicz 1990, Santos \& Sano 2001b). No PEIB, ocorre a aproximadamente $1.400 \mathrm{~m}$ de altitude formando pequena população em solo arenoso.

\section{Ichnanthus P. B eauv., Ess. A grostogr. 56. 1812.}

I chnanthus é composto por 33 espécies neotropicais e uma pantropical (Clayton \& Renvoize 1986). As espécies deste gênero são comumente encontradas em bordas de matas, mas algumas também podem ocorrer em cerrado aberto ou em matas densas (J udziewicz 1990). N o PEIB, ocorrem duas espécies.

25. Ichnanthus inconstans (Trin. ex Nees) Döll, in M art. \& Eichl., FI. bras. 2(2): 284. 1877.

Fig. 8. A-E.

Planta perene, 0,5-1,15 m alt., rizomatosa, ereta, as vezes decumbente; nós glabrescentes. Bainhas foliares densamente pilosas a glabrescentes, margem pilosa, alguns tricomas com base tuberculada; colo densamente piloso; lígula membranoso-ciliada, curtamente membranosa, longamente ciliada; lâminas foliares 3-10 x 0,5-1,3 cm, lanceoladas a elíptico-lanceoladas, planas, pilosas a glabras em ambas as faces, ápice acuminado, margem curtamente serreada, base subcordada, sem pecíolo. Inflorescência 5-12 x 2-8 cm, paniculada típica, subaberta a aberta, raramente pouco ramificada, ramos secundários quando presentes muito curtos, não ultrapassam ca. $1 \mathrm{~cm}$ compr. E spiguetas 2,7-3,7 x 0,6-0,9 $\mathrm{mm}$, estreitamente elíptico-lanceoladas, glabras ou escabérulas; gluma inferior 2,5-3,2 x 0,6-0,8 mm, 3(5)-nervada, estreitamente elíptico-lanceolada, ápice caudado, escabérula ou glabra, nervura central fortemente marcada; gluma superior 2,6-3,7 x 0,6-0,9 mm, 5-nervada, estreitamente elípticolanceolada, ápice agudo a caudado, escabérula em direção ao ápice, ápice com curta pilosidade, nervura central fortemente marcada; antécio inferior portando flor masculina; lema inferior 2,7-3,7 x 0,6-0,9 mm, 5(7)-nervado, estreitamente elíptico-lanceolado, ápice agudo, portando pilosidade; pálea inferior membranácea; antécio superior frutífero; lema superior com alas de 0,3-0,7 mm compr., parcialmente aderidos à base do lema superior, o conjunto lema e pálea superiores é glabro de consistência coriácea e ápice cuspidado; estames vinosos. C ariopse não observada.

Material selecionado: 25.V.1988, P. Andrade 1214 (BHCB); 20.VI.1991, R.C. Oliveira 20 (CEN n.v., CES), RB); 2.XI.1991, R.C. Oliveira s.n. (CESJ 26221, RB); 19.XII.2003, F.M. Ferreira et al. 573 (CESJ, RB); 20.XII.2003, F.M. Ferreira et al. 609 (CES), RB); 21.XII.2003, F.M. Ferreira et al. 615, 616 (CES), RB); 4.II.2004, R. Dias-M elo et al. 143 (K, RB, SP); 19.I.2005, R.C. Forzza et al. 3946 


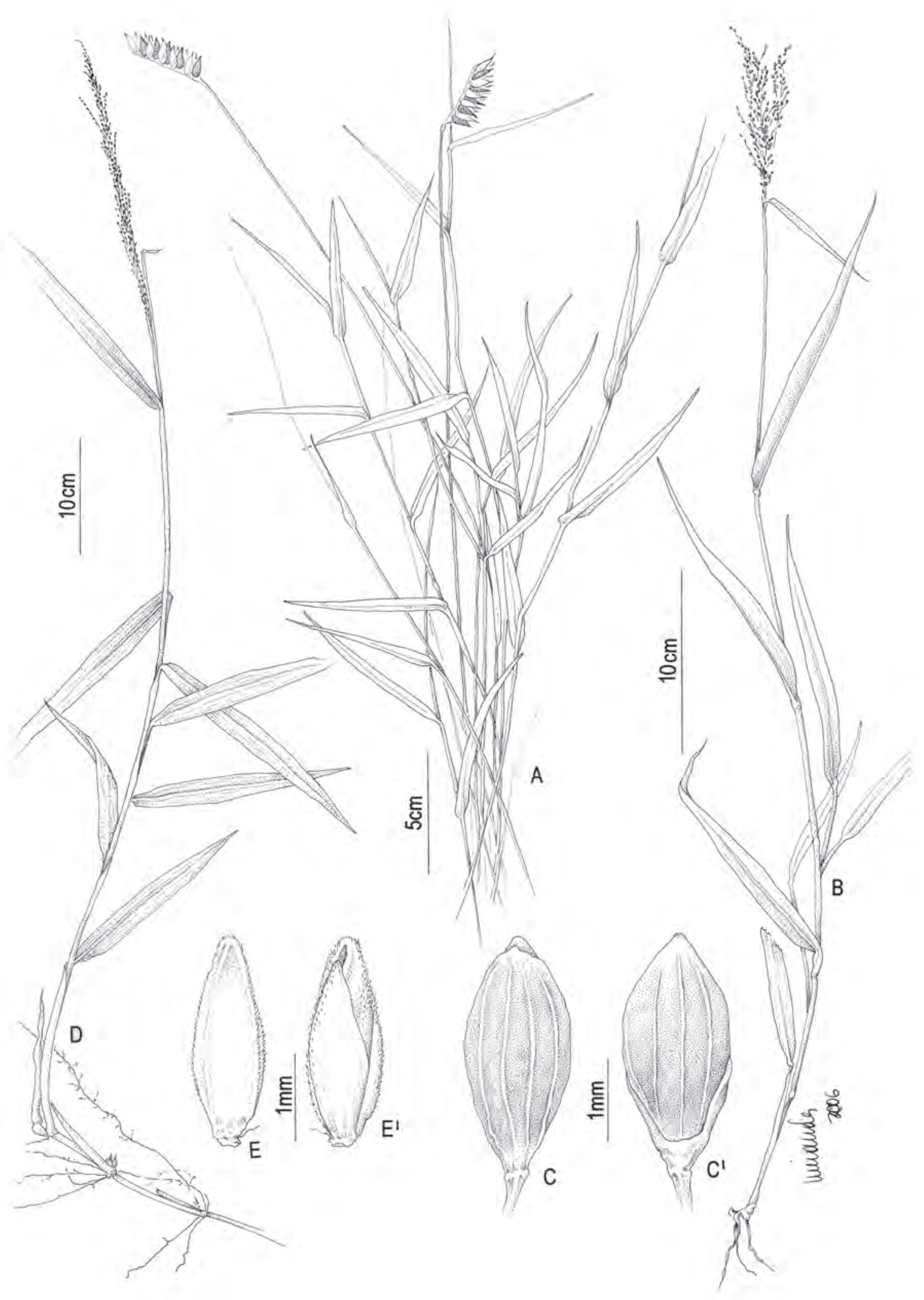

Fig. 7: A Echinolaena inflexa: hábito. B-C Homolepis glutinosa: B. hábito; C. espigueta vista da gluma inferior; C'. espigueta vista da gluma superior. D-E Panicum rude: D. hábito; E. espigueta vista da gluma inferior; E'. espigueta vista da gluma superior. (A Forzza 3297; B-C Dias-M elo 170; D-E Eiterer S.n. (CESJ 25685)). 
(CEPEC, K, M BM , RB, SP); 9.VIII.2005, R. Dias-M elo et al. 292 (CE$P E C, K, M B M, R B, S P)$.

Distribuição geográfica e habitat: a espécie ocorre no Peru, B rasil, B olívia, Paraguai e A rgentina (Renvoize 1984, Boechat 2005). No Brasil, essa espécie ocorre em Roraima, M aranhão, Ceará, B ahia, Distrito Federal, Goiás, M ato Grosso, M ato Grosso do Sul, M inas Gerais, São Paulo, Paraná e Santa Catarina, em cerrado e cerradão, campo, campo rupestre, sendo menos freqüentemente em áreas sombreadas de mata e em áreas arenosas (B oechat 2005). No PEIB, Ichnanthus incionstans é mais frequente nas formações florestais, tanto em seu interior quanto nas bordas. Porém, al guns indivíduos foram observados no campo rupestre em fendas na rocha e em solo arenoso.

A Iguns materiais examinados do PEIB apresentam "envassouramento" (caule ereto ramificado na parte superior) ou espiguetas teratológicas conforme mencionado por também por B oechat (2005) e colmos freqüentemente tornandose sublenhosos. A autora cita o material coletado em Ibitipoca como "material examinado atípico" e acrescenta que os exemplares que possuem "envassouramento", foram coletados sobre pedras quartzíticas e em campo rupestre com abundância de arenito. Tal fenômeno é resultado da proliferação dos ramos superiores e redução nas dimensões da planta, fol has, panícula e espiguetas, tendo sido descrito por Stieber (1982) como resposta ao pastoreio.

26. Ichnanthus leiocarpus (Spreng.) K unth, Rev. gram. 2: 507.1831.

Fig. 8. F-H.

Planta perene, 0,3-1,5 $\mathrm{m}$ alt. rizomatosa, ereta ou decumbente; nós pilosos a glabrescentes. Bainhas foliares pubescentes a glabrescentes, margem pubescente; colo lanoso a seríceo; lígula pilosa; lâminas foliares 4,5-9,5 x 0,9-1,8 cm, estreitamente elíptico-lanceoladas, setosa a glabrescente em ambas as faces, ápice agudo, margem escabérula às vezes portando tricomas hirsútulos, base atenuada, curtamente pecioladas. Inflorescência 4,5-15,5 x 1-2 cm, panícula típica, contraída a subaberta, moderadamente a muito ramificada. E spiguetas 4-5 x 1,2-2 mm, lanceoladas, às vezes lateralmente comprimidas, escabérulas a glabras; gluma inferior 4,8-5 x 1,2-1,8 mm, 3-nervada, lanceolada, ápice cuspidado, escabérula, principalmente na nervura central; gluma superior 4,2-5 x 1-1,5 mm, 5-nervada, lanceolada, ápice agudo a cuspidado, escabérula, principalmente em direção ao ápice, nervura central fortemente marcada; antécio inferior neutro ou estaminado; lema inferior, 4-5 x 1,2-2 mm, (3)5-nervado, lanceolado, ápice agudo a cuspidado, escabérulo, principalmente em direção ao ápice; pálea inferior membranácea; antécio superior frutífero 3,5-4 x 1-1,2 mm; lema superior com al as de 1,3-1,8 mm compr., não aderidas à base do lema superior; o conjunto lema e pálea superiores apresenta ápice agudo a cuspidado, glabro, com leve rugosidade Iongitudinal, coriáceo. C ariopse não observada.
M aterial selecionado: 6.II.1989, L. Krieger et al. s.n. (CESJ 25300, RB); 19.X.2003, R. Dias-Melo et al. 15 (RB); 21.XII.2003, F.M. Ferreira et al. 614 (CES), RB); 4.Il.2004, R. D ias-M elo et al. 138 (K, RB); 31.III.2004, R. Dias-M elo et al. 182 (K, M B M , RB, SP); 17.III.2005, R. M arquete et al. 3585 (RB); 26.V.2005, R. C. Forzza et al. 3983 (K, RB, SP); 9.VIII.2005, R. Dias-M elo et al. 294 (K, M B M , RB, SP).

Distribuição geográfica e habitat: I chnanthus leiocarpus ocorre em ambientes florestais do B rasil, Venezuela, Guiana e Trindade (Stieber 1982, Renvoize 1984, J udziewicz 1990). No B rasil, ocorre do Ceará ao Rio Grande do Sul, em borda ou interior de florestas secundárias, pluviais, higrófilas, na caatinga arbórea, em solo com afloramento de rochas e em encostas (B oechat 2005). No PEIB, foi coletada tanto no interior quanto na borda de matas.

M elinis P. B eauv., Ess. A grostogr. 54. 1812.

Gênero africano composto por 11 espécies de morfologia muito semel hante sendo, portanto, de difícil delimitação (Renvoize 1984). Para o neotrópico são citadas apenas duas espécies (Zuloaga et al. 2003), e destas uma ocorre no PEIB.

27. Melinis minutiflora P. Beauv., Ess. A grostogr. 54. 1812.

Fig. 8. I.

Plantas perenes, $35-75 \mathrm{~cm}$ alt., decumbentes; nós pilosos. Bainhas foliares portando tricomas glandulares; lígula pilosa; lâminas foliares 3-15 x 0,3-0,7 cm, linear-lanceoladas, planas, portando tricomas glandulares em ambas $\mathrm{s}$ faces, ápice agudo, base reta. Inflorescência 10-24 cm compr., panícula típica. E spigueta 2-2,2 1 mm compr., escabérula; gluma inferior 0,1-0,2 x 0,2 mm, ca. 1/5 da gluma superior, amplamente ovada, ápice emarginado; gluma superior 2-2,2 $x 1 \mathrm{~mm}$, oval, ápice bífido, a nervura central prolongando-se numa arístula; lema inferior 2-2,2 $0,6 \mathrm{~mm}$, bífido, aristado, arista de 5-12 mm compr., antécio superior frutífero, ca. 2 $\mathrm{mm}$ compr. C ariopse não vista.

Material examinado: 25.VI.1987, H. C. Souza et al. s.n. (BHCB 14584); 18.VI.1994, M. C. M. Garcia 3 (CESJ); 26.X.2004, R. DiasMelo et al. 186 (K, MBM, RB, SP).

Distribuição geográfica e habitat: Melinis minutiflora é uma espécie africana que se tornou pantropical devido à introdução para forragens, principal mente na A mérica do Sul. É comum em locais abertos e alterados (A rce \& Sano 2001). Ocorre em diversos locais no Parque, principalmente onde a visitação é intensa, como borda de trilhas, cachoeiras e entradas das grutas, o que indica certo grau de impacto na área.

O plismenus P. B eauv., FI. Oware 2: 14. 1807 (1810).

Gênero pantropical, que compreende de 10 a 15 espécies de ambiente florestal com grande variação morfológica (L onghi-Wagner 2001b). Para o neotrópico, são citadas três espécies (Zuloaga et al. 2003), uma é registrada no PEIB. 


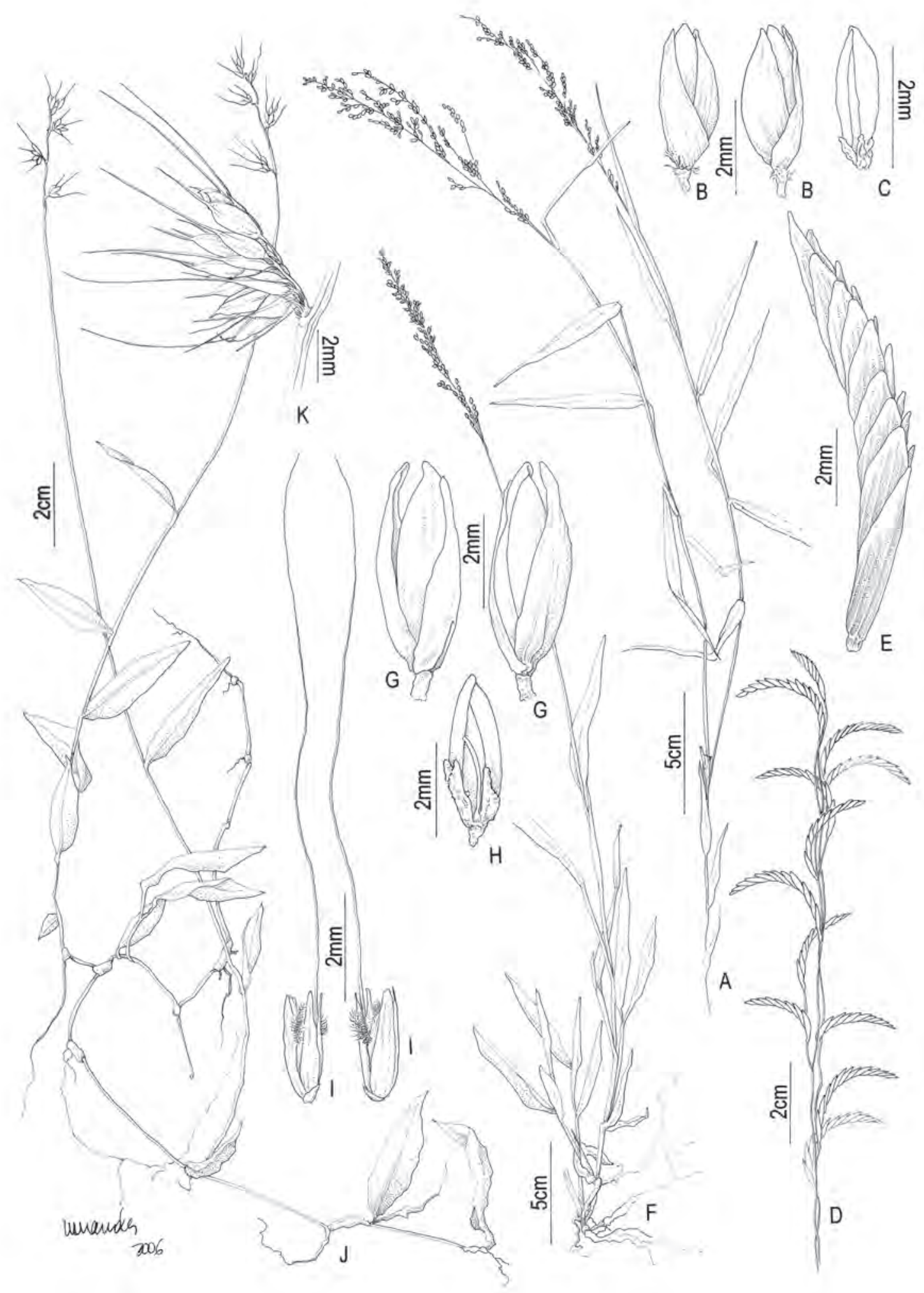

Fig. 8: A -E Ichnanthus inconstans: A. hábito; B. espigueta vista da gluma inferior; B'. espigueta vista da gluma superior; C. lema superior com apêndices aliformes na base; D. ramos da inflorescência teratológica; E. detalhe do ramo florífero teratológico. F-H I. leiocarpus: F. hábito; G-G'. espigueta vista lateral; $H$. lema superior com apêndices al iformes na base. I-I' M elinis minutiflora: espigueta vista lateral. J-K 0 plismenus hirtellus: J. hábito; K. racemo com grupo de espiguetas. (A -E Ferreira 574; F-H Forzza 3296; I Dias-M elo 186; J-K Forzza 3315). 
28. Oplismenus hirtellus (L .) P. B eauv., Ess. A grostogr. 54: 168. 1812.

Fig. 8. J-K.

Plantas perenes, $24-56 \mathrm{~cm}$ alt., estol oníferas, decumbentes. Bainhas foliares com tricomas esparsos em sua extensão e denso na margem; colo piloso; lígula membranoso-ciliada; lâminas foliares 1-4,5 x 0,4-1 cm, linear-lanceoladas a ovallanceoladas, pubescentes em ambas as faces, ápice agudo, base pubescente, margem escabra. Inflorescência 2-17 cm compr., com 3-6 ramos unilaterais espiciformes de 2-7 mm compr., com grupos de espiguetas congestas distanciadas 0,3-1,5 cm entre si; ráquis esparsamente híspida, escabra nas margens; ráquis 0,5-1 mm larg. E spiguetas pubescentes; gluma inferior 1,2-3 mm compr., arista 3-7 mm compr.; gluma superior 1,7-2 mm compr., arista de 1-2 mm compr.; antécio inferior neutro; pálea inferior ausente; antécio superior 2-2,3 x 0,6-0,8 mm, liso e brilhoso. C ariopse não observada.

Material examinado: 31.III.2004, R.C. Forzza et al. 3315 (K, RB).

Distribuição geográfica e habitat: 0 plismenus hirtellus é uma espécie pantropical. No neotrópico ocorre do M éxico e A ntil has até a A rgentina, entre 0 a $2.000 \mathrm{~m}$ de altitude, em ambientes florestais e locais úmidos, no interior de mata, menos comumente em borda de mata (Longhi-Wagner 2001b). No PEIB, foi coletada em borda de mata.

\section{Panicum L., Sp. PI. 1: 55. 1753.}

Em uma circunscrição mais ampla, Panicum é composto por cerca de 600 espécies (Zuloaga 1987) e incluía um grande número de táxons pertencentes a outros gêneros de Paniceae (Guglieri et al. 2009). Com o avanço dos estudos utilizando diferentes abordagens, alguns subgêneros propostos por Zuloaga (1987) foram elevados à categoria de gênero, como Steinchisma, Dichanthelium, Phanopyrum e M egathyrsus (Guglieri et al. 2009). Entretanto, o maior impacto na circunscrição de Panicum ocorreu e vem ocorrendo através dos estudos baseados em dados moleculares. Com isso, algumas espécies aqui tratadas como Panicum já foram segregadas para outros gêneros. Panicum aristellum foi transferida para C anastra (Zuloaga et al. 2006); P. discrepans para Cyphonanthus (M orrone et al. 2007); espécies de Panicum sect. Lorea foram segregadas em A pochloa e Renvoizea (Sede et al. 2008); e os táxons de Panicum sect. Stolonifera estão sendo transferidos para um novo gênero, 0 cellochloa (Sede et al. inédito). A pesar destas recentes mudanças na circunscrição de Panicum, no presente estudo optamos por apresentar as espécies com seu posicionamento antigo, uma vez que al gumas combinações ainda são inéditas.

29. Panicum aristellum Döll in M art. \& Eichl., FI. bras. enum. pl. 2(2): 221. 1877.

Fig. 9. A.
Planta perene, 1,5-2 m alt., cespitosa, ereta; nós glabros. Bainhas foliares com tricomas marginais densos a subdensos; colo glabro, sem lígula externa; lígula membranosociliada; lâminas foliares 18-94 x 1-1,5 cm, lineares, planas, agudas, face abaxial escabra ou glabra, face adaxial glabra, margem escabra, base reta, simétrica, sem pecíolo. Inflorescência $33-40 \mathrm{~cm}$ compr., panícula típica, subaberta, quando jovem vinácea, axilas pilosas; ráquis escabra e portando alguns tricomas hirsútulos, caducos com a maturidade da inflorescência. E spiguetas 5-6 mm compr., estreito elípticas, solitárias, glabras; glumas aristuladas, arístulas de $(0,5) 1-1,2$ mm compr.; gluma inferior 1,5-2,8 mm compr., 1-3-nervada, base não abraçando a gluma superior, nervura central evidente e escabra, as outras duas nervuras quando presentes são fracamente marcadas; gluma superior 4-4,8 mm compr., 5-nervada, nervuras evidentes, a central escabra e as outras lisas; antécio inferior com flor masculina; lema inferior 3-3,2 mm compr., 3-5-nervado, ápice agudo ou aristulado; pálea inferior 2,9-3,1 mm compr., subigual ao lema inferior; antécio superior frutífero, 3-3,3 mm compr., sem estípite na base, liso, glabro, cartilaginoso; estigmas castanhos e anteras roxas. C ariopse não observada.

Material examinado: 19.X.2003, R. Dias-Melo et al. 18 (RB); 8.III.2006, F.M . Ferreira et al. 1021 (CES), RB).

Distribuição geográfica e habitat: espécie com distribuição restrita ao Brasil, de M inas Gerais até o Rio Grande do Sul, em terrenos arenosos e brejos e em borda de floresta (Zuloaga et al. 2001a). No PEIB, foi col etada em mata ciliar na margem do Rio do Sal to onde forma grandes populações.

30. Panicum cyanescens N ees ex Trin., Gram. Panic. 202. 1826.

Fig. 9. B-C.

Planta perene, $26-36 \mathrm{~cm}$ alt., rizomatosa, cespitosa às vezes decumbente; nós pilosos a glabros. Bainhas foliares pilosas a glabrescentes; colo glabro; lígula membranosa; lâminas foliares $2,5-4,5 \times 0,3-0,5 \mathrm{~cm}$, linear-lanceoladas a lanceoladas, planas, ambas as faces pilosas a glabrescentes, ápice agudo-acuminado, margem pilosa a glabrescente, base levemente arredondada, simétrica, sem pecíolo. Inflorescência 4,5-6 × 2-5 cm., panícula típica, aberta, axilas glabras; ráquis glabra. E spiguetas 1,3-1,6 x 0,9-1 mm, amplamente ovada a ovada, solitárias, glabrescentes; gluma inferior 1,1-1,2 x 0,4-0,6 mm, 3(5)-nervada, ovada, ápice agudo, as vezes mucronado, glabra a glabrescente, base não abraçando a gluma superior; gluma superior 1,3-1,5 x 0,6-0,8 mm, 3-5-nervada, ovada, ápice acuminado, glabra a glabrescente; antécio inferior com flor masculina; lema inferior 1,3-1,6 x 0,9-1 mm, 5-nervado, ápice acuminado, glabro a glabrescente; pálea inferior membranácea; antécio superior frutífero, 1,3-1,5 x 0,6-0,8 mm, glabro, foliáceos, ápice acuminado. Cariopse não observada. 
Material selecionado: 6.II.1989, L. Krieger et al. S.n. (CEN n.v., CESJ 25878, RB); 3.II.1993, R.C. Oliveira 141 (CESJ, RB); 5.II.2004, R. Dias-M elo et al. 153 (K, M BM RB, SP); 30.III.2004, R. Dias-M elo et al. 174 (RB).

Distribuição geográfica e habitat: Panicum cyanescens ocorre desde a A mérica Central até B rasil e A rgentina, em campos naturais e campos de altitude, em solo arenoso, brejos ou alagados (L onghi-Wagner \& Todeschini 2004). No PEIB, ocorre entre 1.400 e $1.560 \mathrm{~m}$ de altitude, formando populações esparsas em campo úmido. 1978.

31. Panicum euprepes Renvoize, Kew Bull. 32(2): 422.

Fig. 9. D-E.

Planta perene, 0,6-1,2 $\mathrm{m}$ alt., cespitosa; nós glabros. Bainhas foliares pilosas, glabrescentes no ápice, tricomas marcescentes nas margens; colo glabro, sem lígula externa; lígula membranoso-ciliada; lâminas foliares 10-25 x 0,3-0,5 $\mathrm{cm}$, lineares, planas, tornando-se involutas com o envelhecimento da planta, ambas as faces glabras, ápice agudo e pungente, margem escabra, portando longos tricomas na porção basal, base reta, simétrica, sem pecíolo. Inflorescência 8-14 x 4-7 cm, rosada ou verde passando a vinácea, panicula típica, subaberta; axilas pilosas a glabrescentes nas ramificações basais e glabras nas apicais; ráquis glabra. E spiguetas 2,2-2,5 x 1,1-1,4 mm, ovais, solitárias, glabras; gluma inferior 1,2-1,7 x $1 \mathrm{~mm}$, 3-nervada, ovada a amplamente ovada, ápice obtuso, base não abraçando a gluma superior, glabra, nervura central fortemente marcada formando uma quilha; gluma superior 2,2-2,5 x 1,1-1,4 mm, 5-nervada, ovada, ápice obtuso, glabra, nervura central fortemente marcada; antécio inferior portando flor masculina; lema inferior 2,2-2,5 $\mathrm{x}$ 1,1-1,4 mm, 5-nervado, ápice obtuso, glabro; pálea inferior membranácea; antécio superior frutífero, 1,8-2 x 0,8-1 mm, ápice subagudo, lustroso, cartáceo; lema superior 1-nervado; estigmas rosados quando jovens, passando a roxos quando maduros; anteras atro-purpúreas. C ariopse ca. 0,7 x 0,3 mm.

M aterial selecionado: 2.X.1970, L. Krieger s.n. (BHCB, CEN n.v., CEPEC n.v., CESJ 9471); 8.X.1987, P. Andrade et al. 1048 (BHCB); 5.II.2004, R. Dias-M elo et al. 150 (K, RB, SP); 30.III.2004, R.C. Forzza et al. 3283 (K, M BM, RB, SP); 30.III.2004, R. Dias-M elo et al. 173 (K, M BM , RB, SP); 26.VII.2004, R.C. Forzza et al. 3549 (CEPEC, K, M BM , RB, SP); 18.III.2005, R. M arquete et al. 3602 (RB); 27.V.2005, R.C. Forzza et al. 3996 (CEPEC, K, M B M, RB, SP); 10.VIII.2005, R. Dias-M elo et al. 305 (K, RB, SP); 23.I.2007, F. M. Ferreira et al. 1208 (RB).

Distribuição geográfica e habitat: ocorre nos campos rupestres da B ahia e M inas Gerais, entre 1.300 e 1.600 m de altitude (Renvoize 1984). No PEIB, foi coletada em diferentes locais, entre 1.400 e 1700 m de altitude, em campo encharcável, campo rupestre arbustivo e próximo de mata de galeria, em solo arenoso, arenoso-úmido ou pedregoso.

32. Panicum ovuliferum Trin., G ram. Panic. 191. 1826. Fig. 9. F-G.
Plantas perenes, $25-46 \mathrm{~cm}$ alt., decumbentes, radicantes nos nós inferiores; nós pilosos. Bainhas foliares pilosas a glabrescentes, margem pilosa; colo piloso; lígula membranosa com ápice ciliolado; lâminas foliares 2,5-7 x 0,4-0,9 cm, lanceoladas, planas, ápice acuminado, margem escabra, base assimétrica, com longos tricomas próximo a região ligular, com pecíolo, face adaxial escabra e com tricomas esparsos, face abaxial escabra. Inflorescência jovem, ca. 1,5 x 0,3 cm, paniculada, ráquis escabérula a glabrescente, axilas glabras. E spiguetas 3,8-4,3 x 1,7-2 mm, oval-lanceoladas, solitárias, hirsutula; gluma inferior 2,8-3 x 1,3-1,7 mm, 3-nervada, ovada a oval-lanceolada, ápice obtuso, base abraçando a gluma superior, pilosa entre as nervuras e nas margens, al guns tricomas com base tuberculada; gluma superior 3,8-4,3 x 1,7-2 mm, 5-7-nervada, oval-lanceolada, ápice subagudo, agudo até acuminado, pilosa; antécio inferior neutro; lema inferior 3,8-4,3 x 1,7-2 mm, 5-7-nervado, oval-lanceolado, ápice obtuso a agudo, piloso a glabrescente; pálea inferior ausente; antécio superior frutífero, 3,6-4,1 x 1,7-2 mm, com marcas de nervuras no ápice, ápice apiculado, glabro, com pouca rugosidade tranversal, membranáceo a coriáceo. Cariopse não observada.

M aterial examinado: 6.III.2006, F. M. Ferreira et al. 947 (CES), RB); 23.I.2007, F. M. Ferreira et al. 1204 (RB).

Distribuição geográfica e habitat: ocorre na Colômbia, Venezuela, Bolívia, Paraguai, A rgentina e Brasil, nas Regiões Centro-O este, Sudeste e Sul em interior de mata (Zuloaga et al. 2001a). No PE IB, há somente uma coleta da espécie no interior de mata na Gruta dos Coel hos.

33. Panicum rude $\mathrm{N}$ ees, A grost. bras. in $\mathrm{M}$ art., $\mathrm{Fl}$. bras. enum. pl. 2: 158. 1829.

Fig. 7. D, E.

Plantas perenes, ca. $1 \mathrm{~m}$ alt., cespitosas; nós glabros. Bainhas foliares pubérulas, margem glabra; colo ciliado, castanho-escuro; lígula membranoso-ciliada; lâminas foliares $14-23 \times 2-2,5 \mathrm{~cm}$, pseudopecioladas, lanceoladas, escabérulas em ambas as faces, ápice agudo, margem ciliada, base pubérula. Inflorescência ca. $21 \mathrm{~cm}$ compr., panícula com muitos ramos unilaterais espiciformes. Espiguetas 2-2,5 x 0,6-1,8 mm, elíptico-lanceoladas, agudas a subagudas, pilosas; gluma inferior ca. 2,3 x 1,7 mm, 3-nervada, ápice agudo a subagudo, escabérula, nervura central escabra, com um sutil achatamento lateral; gluma superior ca. 2,2 x 0,5 mm, 3-5-nervada, ápice agudo, hispídula em toda sua extensão, passando a escabra em direção ao ápice, principalmente nas nervuras; antécio inferior neutro; lema inferior ca. 1,6 x 0,4 mm, 3-nervado, hispídulo em toda sua extensão; pálea inferior ausente; antécio superior ca. 1 × 0,4 mm, não papiloso, coriáceo. C ariopse não observada.

Material examinado: 2.XI.1991, M. Eiterer S.n. (CESJ 25685); 24.I.2007, F. M. Ferreira 1237 (RB). 


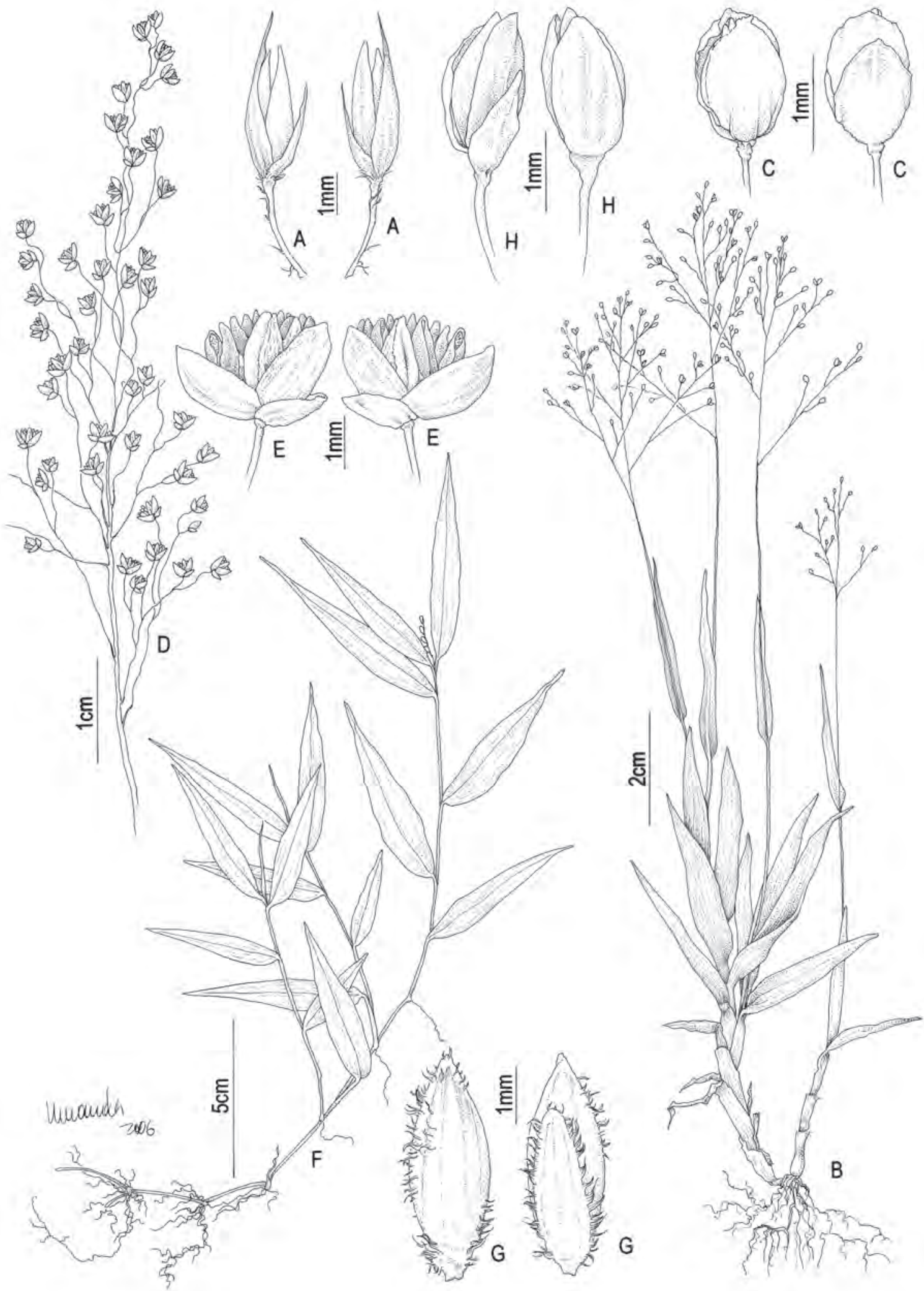

Fig. 9: A. Panicum aristellum: espigueta. B-C P. cyanescens: B. hábito; C. espigueta vista da gluma superior; C'. espigueta vista da gluma inferior. D-E P. euprepes: D. inflorescência; E. espigueta vista lateral. F-G P. ovuliferum: F. hábito; G. espigueta vista da gluma superior; G'. espigueta vista da gluma inferior. H P. sellowii: espigueta vista da gluma inferior; $\mathrm{H}^{\prime}$. espigueta vista da gluma superior. (A Dias-M elo 18; B-C Dias-M elo 153; D-E Forzza 3549; F-G Ferreira 947; H Dias-M elo 139). 
Distribuição geográfica e habitat: espécie muito polimórfica restrita ao Brasil, sendo comum no interior ou borda de florestas de 0 a 1900 m.s.m. (Zuloaga \& Sendulsky 1988). No PEIB, foi coletada na margem do rio do Salto na região da Prainha formando grandes touceiras juntamente com $P$. aristelum. Essas populações ficam parcialmente submersas nos períodos de cheia do rio durante a época chuvosa.

34. Panicum sellowii N ees, A grost. bras. in $\mathrm{M}$ art. \& Eichl., Fl. bras. enum. pl. 2(1): 153. 1829.

Fig. 9. H.

Planta perene, $15-35 \mathrm{~cm}$ alt., decumbente, radicante nos nós inferiores; nós pilosos a glabrescentes. Bainhas foliares pilosas, alguns dos tricomas com base tuberculada; colo piloso; lígula membranosa; lâminas foliares 1,7-11,5 x 0,4-1,2 $\mathrm{cm}$, linear-lanceoladas a lanceoladas, planas, ápice acuminado, margem escabra, base arredondada, às vezes assimétrica, sem pecíolo, com longos tricomas próximo à região ligular, ambas as faces pilosas a glabrescentes. Inflorescência 10-13 x 5-8,5 cm, panícula típica, laxa, pauciflora; ráquis escabra e hirsuta a glabrescente; axilas glabras. E spiguetas 1,8-2,2 x 0,8-1 mm, ovais, solitárias, ápice subagudo; gluma inferior 1-1,3 x 0,3-0,5 mm, 3-nervada, lanceolada a oval-Ianceolada, ápice agudo, base não abraçando a gluma superior, glabrescente; gluma superior 1,8-2 x 0,8-1 mm, 5-nervada, ovada a oval lanceolada, ápice subagudo a agudo, glabrescente; antécio inferior neutro; lema inferior 1,8-2 x 0,8-1 mm, 5-nervado; pálea inferior reduzida, paleácea; antécio superior frutífero, 1,8-2,2 x 0,8-1 mm, castanho-escuro na maturação, ápice apiculado, glabro, lustroso, com pouca rugosidade transversal, cartáceo. C ariopse não observada.

Material examinado: 3.II.1993, R.C. Oliveira S.n. (CES) 26368, RB ); 4.II.2004, R. Dias-M elo et al. 139 (RB).

Distribuição geográfica e habitat: ocorre do sul do México e A ntilhas até ao norte da A rgentina, em locais sombreados, raramente em locais abertos, de 200 a $1.600 \mathrm{~m}$ de altitude (Renvoize 1984; J udziewicz 1990). No B rasil, ocorre no Pará e nas Regiões Nordeste, Centro-Oeste, Sudeste e Sul, em cerrados, campos abertos, secos e arenosos ou úmidos, campos sujos e em interior de mata (Zuloaga et al. 2001a). No PEIB , foi coletada no interior de mata (ca. 1.326 $\mathrm{m}$ de altitude) e também em campo com solo argiloso.

\section{Paspalum L., Syst. Nat. (ed. 10) 2: 846, 855, 1359. 1759.}

Gênero com aproximadamente 400 espécies, amplamente distribuídas em áreas tropicais ou subtropicais, com o centro de diversidade no neotrópico, especialmente no Brasil, onde ocorrem cerca de 300 espécies (Clayton \& Renvoize 1986, Judziewicz 1990). No PEIB, Paspalum está representado por sete espécies.

35. Paspalum dilatatum Poir., Encycl. 5: 35. 1804.

Fig. 10. A-B.
Plantas perenes, 1,14-1,40 m alt., cespitosas; nós glabros. Bainhas foliares glabrescentes ou pilosas, portando na margem e no ápice esparsos tricomas de base tuberculada; lígula membranosa; prefoliação não vista; lâminas foliares 9-52 x 0,5-2,2 cm, lanceoladas, planas, ápice agudo, base não estreitada, margem escabra, glabras em ambas as faces, lanuginosa próximo à região ligular. Inflorescência com 6-8 ramos unilaterais espiciformes, alternos $6-12 \mathrm{~cm}$ compr., os basais maiores que os apicais, axilas pilosas; ráquis 0,8-1 $\mathrm{mm}$ larg., glabras, papilosas, verdes ou estramíneas, margem glabra, lisa, não alada, terminando em um ou dois pares de espiguetas; pedicelos glabros, lisos. E spiguetas 2,3-2,7 x 1,5-1,7 mm, binadas, oblongo-lanceoladas, castanhas-claras, ápice subagudo, às vezes apiculado, margens e porção central da gluma superior e lema inferior portando tricomas seríceos; gluma inferior ausente; gluma superior 2,2-2,6 x 1,5-1,7 mm, 5-nervada, ápice apiculado, membranácea, não alada; antécio inferior neutro; lema inferior 2,3-2,7 x 1,5-1,7 mm, 3-nervado, ápice subagudo, membranáceo, não plicado; pálea inferior ausente; antécio superior frutífero, 2,3-2,7 x 1,5-1,7 mm, oval, papiloso, cartilaginoso, castanho-claro; anteras nigrescentes. C ariopse não observada.

M aterial examinado: 18.III.2005, R. Dias-M elo et al. 241 (CEPEC, $K, M B M, R B, S P)$.

Distribuição geográfica e habitat: espécie nativa do sul do Brasil e norte da Argentina, atualmente é amplamente cultivada pelo mundo nas áreas subtropicais e tropicais como forrageira (J udziewicz 1990). N o PEIB, ocorre apenas na trilha do centro de visitantes para o camping, formando população esparsa em solo arenoso e em local sombreado.

36. Paspalum hyalinum Nees ex Trin., Gram. Panic. 103. 1826.

Fig. 10. C-D.

Plantas perenes, $28-42 \mathrm{~cm}$ alt., cespitosas, rizomas curtos; nós glabros. Bainhas foliares com longos tricomas, margem inteira; lígula membranosa; prefoliação conduplicada ou involuta; lâminas foliares 2,2-14,3 x 0,1-0,2 cm, linear-lanceoladas, planas ou involutas, ápice agudo, margem com tricomas tuberculados, ambas as faces pilosas. Inflorescência com 2 ramos unilaterais espiciformes de 1,2-3,5 $\mathrm{cm}$ compr., alternos, axilas com longos tricomas; ráquis ca. $0,5 \mathrm{~mm}$ larg., glabra, lisa, estramínea, margem ciliada, não alada, terminando em uma espigueta; pedicelos glabros ou pilosos na base, escabérulos. E spiguetas 1,1-1,3 x 0,6-0,8 $\mathrm{mm}$, solitárias, oblongo-elípticas, ápice subagudo a obtuso, glabras, estramíneas; gluma inferior ausente; gluma superior 1,1-1,3 x 0,6-0,8 mm, 4-nervada, ápice subagudo a obtuso, glabra, hialina na porção central, não alada, membranácea; antécio inferior neutro; lema inferior 1,1-1,3 x 0,6-0,8 mm, 2-nervado, ápice subagudo, glabro, não plicado, hialino na porção central, membranáceo; pál ea inferior ausente; antécio superior frutífero, 1,1-1,3 x 0,6-0,8 mm, oblongo-elíptico, 
glabro, membranáceo, estramíneo, brilhoso. Cariopse não observada.

M aterial examinado: 8.III.2006, F.M . Ferreira et al. 1022 (CESJ, RB).

Distribuição geográfica e habitat: Paspalum hyalinum ocorre desde a Guiana Inglesa até o Paraguai e B rasil, nas Regiões Centro-O este e Sudeste (Oliveira \& Valls 2001). No PEIB, foi observada apenas uma população que ocorre em campo rupestre arbustivo.

37. Paspalum juerguensii Hack., Repert. Spec. Nov. Regni Veg. 7: 312. 1909.

Fig. 10. E-F.

Plantas perenes, $75-140 \mathrm{~cm}$ alt., cespitosas; nós pilosos. Bainhas foliares glabras, com tricomas tuberculados na margem; lígula membranosa; prefoliação conduplicada; lâminas foliares 5-29 x 0,2-1,9 cm, lanceoladas, planas, ápice agudo, margem escabérula portando esparsos tricomas hirtos, base não estreitada, pilosa próximo à região ligular, face adaxial setosa, abaxial glabra. Inflorescência com 5-16 ramos unilaterais espiciformes, alternos ou opostos 1,5-6 cm compr., os racemos basais maiores que os apicais, axilas pilosas; ráquis 0,4-0,7 mm larg., glabrescente, escabérula, verde ou estramínea, margem não alada, glabra, lisa, terminando em uma par de espiguetas; pedicelos escabérulos. E spiguetas 1,1-1,3 x 0,8-1 mm, binadas, suborbiculares, estramíneas passando a vináceas, ápice subagudo a obtuso, às vezes apiculado, glabras a glabrescentes; gluma inferior ausente; gluma superior 1-1,2 x 0,8-1 mm, 3-nervada, nervura central não projetando-se em quilha, ápice obtuso, glabrescente, membranosa, não alada; antécio inferior neutro; lema inferior 1,1-1,3 x 0,8-1 mm, 3-nervado, ápice subagudo, glabrescente, membranoso, não plicado; pálea inferior ausente; antécio superior frutífero, 1,1-1,3 x 0,8-1 mm, amplamente elíptico, glabro, liso, lustroso, cartilaginoso. Cariopse 0,4-0,8 × 0,2-0,6 mm, elíptico a amplamente elíptico, castanho-escuro.

Material examinado: 30.III.2004, R. Dias-M elo et al. 169 (K, RB, SP); 7.III.2005, F.M. Ferreira et al. 985 (CESJ, RB).

Distribuição geográfica e habitat: ocorre no Equador, Bolívia, A rgentina e Brasil, de São Paulo até o Rio Grande do Sul, em florestas secundárias e margens de estradas (Oliveira \& Valls 2001). No PEIB, foi coletada no campo rupestre a cerca de $1.380 \mathrm{~m}$ de altitude, sendo este o primeiro registro de Paspalum juerguensii em M inas Gerais.

38. Paspalum notatum Flüggé, Gram. M onogr., Paspalum 106. 1810.

Fig. 10. G.

Planta perene, ca. $60 \mathrm{~cm}$ alt., cespitosa; nós glabros. Bainhas foliares glabras com tricomas setosos na margem; lígula membranoso-ciliada; prefoliação convoluta; lâminas foliares 4,5-15,5 x 0,2-0,8 cm, lanceoladas, lineares quando jovens, planas ou conduplicadas, ápice agudo, sem estreitamento em direção à base, pubérul as próximo à região ligular, pilosas na face abaxial e glabras a esparsamente hirsuta na face adaxial. Inflorescência com 2 racemos unilaterais espiciformes, conjugados, divergentes, ca. $8 \mathrm{~cm}$ compr., axilas pilosas; ráquis ca. $1 \mathrm{~mm}$ larg., glabra, lisa, verde ou estramínea, margem não alada, lisa, escabra, terminando em uma espigueta; pedicel os escabérul os. E spiguetas 2,9-3,5 x 1,9-3 $\mathrm{mm}$, solitárias, suborbiculares a oval-lanceoladas, obtusas a emarginadas, glabras, estramíneas a verdes; gluma inferior ausente; gluma superior 2,5-3,4 x 2-2,1 mm, 3-5-nervada, ápice emarginado, glabra, membranosa, não alada; antécio inferior neutro; lema inferior 2,5-3,4 x 2-2,1 mm, 3-5-nervado, ápice obtuso, glabro, membranoso, não plicado; pálea inferior ausente; antécio superior frutífero 2,5-3,2 x 2-2,1 $\mathrm{mm}$, com 3-nervuras fracamente marcadas, oval-lanceolado, obtuso, glabro, com pequena rugosidade, estramíneo, cartilaginoso. C ariopse não observada.

M aterial examinado: 6.III.2006, F.M . Ferreira et al. 953 (CESJ, RB).

Distribuição geográfica e habitat: ocorre dos Estados Unidos até Uruguai, A rgentina e Brasil, da Bahia até o Rio Grande do Sul, em ambientes bastante diversificados, geralmente em solos secos (Oliveira \& Valls 2001). No PEIB, ocorre em local de intensa visitação próximo ao centro de informações, em borda de mata. Paspalum notatum é amplamente utilizada em gramados e as variedades mais robustas têm sido selecionadas para pastagens e controle de erosão (Renvoize 1984).

39. Paspalum nutans Lam., Tabl. Encycl. 1: 175. 1791. Fig. 11. A-B.

Plantas perenes, 35-70 cm alt., cespitosa decumbentes; nós pilosos ou glabros. Bainhas foliares glabras, pubescentes nas margens ou totalmente pubescentes; lígula membranosa; prefoliação convoluta; lâminas foliares 4,5-17 x 0,5$1,2 \mathrm{~cm}$, oblanceoladas a lanceoladas, planas, ápice agudo, margem ciliada, não estreitando em direção a base, ambas as faces setosas. Inflorescência com 1-6 ramos unilaterais espiciformes, alternos ca. 2-5,5 cm compr.; ráquis $0,6-0,8$ mm larg., glabra, lisa, esverdeada, margem não alada, lisa, glabra, terminando em uma espigueta; pedicel os glabros ou com tricomas curtos. E spiguetas 2-2,2 x 1-1,2 mm, binadas, obovais, ápice obtuso, estramíneas; gluma inferior ausente; gluma superior 1,9-2,1 x 1-1,2 mm, 5-nervada, ápice obtuso, glabra ou esparsamente pilosa, membranácea, não alada; antécio inferior neutro; lema inferior 2-2,2 x 1-1,2 mm, 5-nervado, ápice obtuso, membranáceo, glabro, não plicado; pálea inferior ausente; antécio superior frutífero, 2-2,2 x 1-1,2 $\mathrm{mm}$, sem nervuras aparentes, elíptico-oboval, glabro, liso a finamente granuloso-estriado. C ariopse não observada.

M aterial selecionado: 5.XII.1992, R.C. Oliveira 126 (CESJ, RB); 3.II.1993, R.C. Oliveira 139 (CES)); 30.III.2004, F.M. Ferreira et al. 


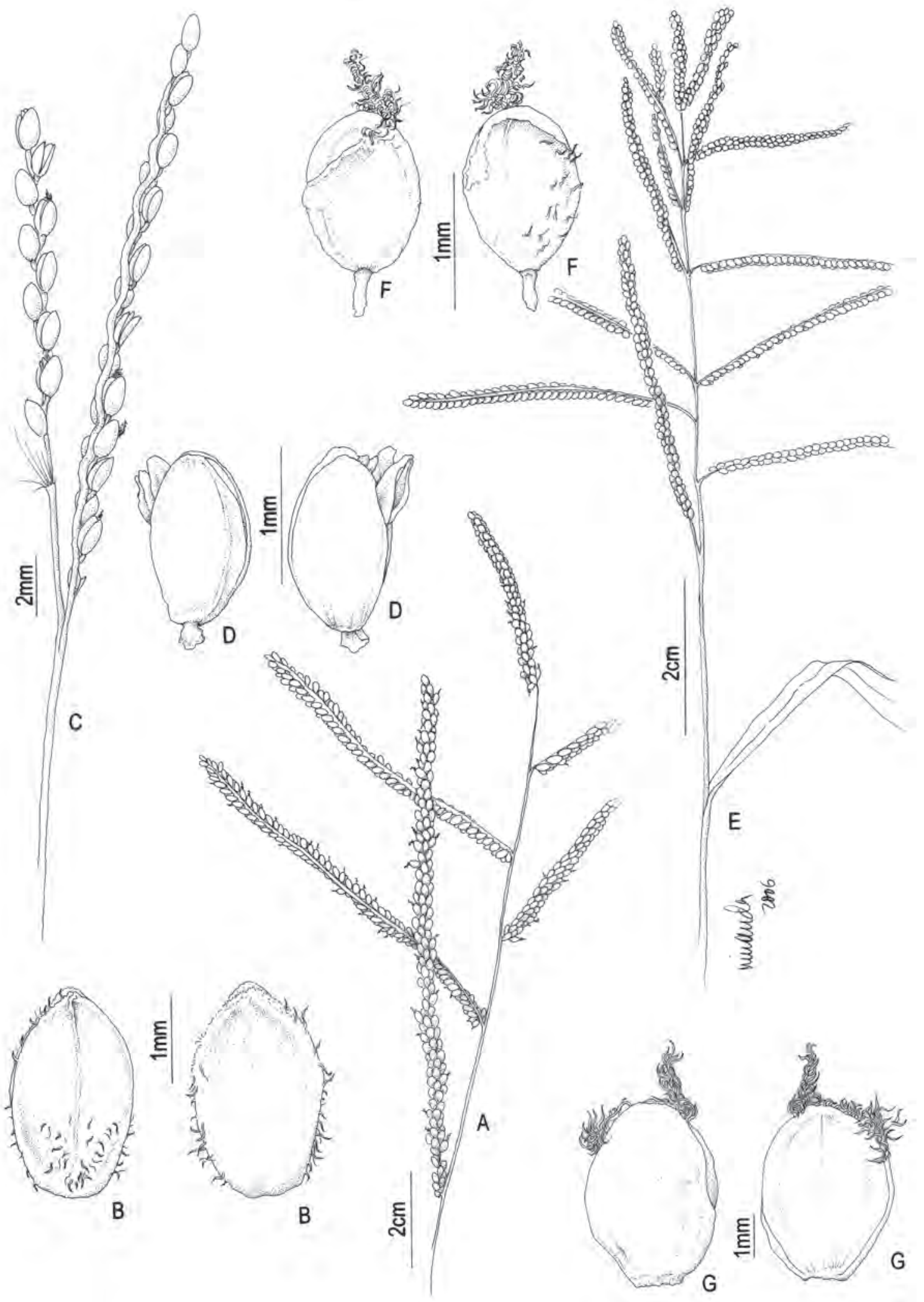

Fig. 10: A -B Paspalum dilatatum: A. inflorescência; B. espigueta vista da gluma superior; B'. espigueta vista do lema inferior. C-D P. hyalinum: C. inflorescência; D. espigueta vista do lema inferior; D'. vista da gluma superior. E-F P. juerguensii: E. inflorescência; $F$. espigueta vista do lema inferior; $F^{\prime}$. espigueta vista da gluma superior. G P. notatum: espigueta vista da gluma superior; $G$ '. espigueta vista do lema inferior. (A-B Dias-M elo 241; C-D Ferreira 1022; E-F Dias-M elo 169; G Ferreira 953). 
723 (RB); 30.III.2004, R. Dias-M elo et al. 178 (K, RB); 31.III.2004, R. Dias-M elo et al. 183 (RB); 17.III.2005, R. Dias-M elo et al. 227 (K, RB); 8.III.2006, F.M. Ferreira et al. 1008 (CES), RB); 23.I.2007, F.M . Ferreira et al. 1203 (RB); 23.I.2007, F.M. Ferreira et al. 1225 (RB).

Distribuição geográfica e habitat: ocorre de Honduras até 0 B rasil e na Ilha M auritius, na Á frica. No B rasil, se distribui do Pará e Pernambuco até Santa Catarina, em locais de meia sombra, em mata secundária baixa e matas do litoral (Oliveira \& Valls 2001). No PEIB, Paspalum nutans foi encontrada em várias localidades como em mata de candeia, no campo rupestre arbustivo, no interior de mata ou nos campos encharcáveis, sempre em locais úmidos e sombreados e em pequenas populações.

40. Paspalum paniculatum L., Syst. Nat. (ed. 10) 855. 1759.

Fig. 11. C-D.

Planta perene, ca. 1,16 m alt., cespitosa; nós pilosos. Bainhas foliares setosas, margem portando tricomas loriformes; lígula membranosa; prefoliação convoluta; lâminas foliares 9,5-43,5 × 0,7-2,1 cm, lanceoladas, planas, ápice agudo, margem escabra, não estreitando em direção à base, setosa em ambas as faces, lanuginosa próximo à região ligular. Inflorescência com ca. 21 ramos unilaterais espiciformes, alternos, 4-12 cm compr., os basais maiores que os apicais, axilas hirsutas; ráquis 0,3-0,4 mm larg., glabra, margem portando esparsos tricomas tuberculados, não alada, verde ou estramínea, terminando em um par de espiguetas; pedicelos escabérulos. E spiguetas 1,3-1,7 x 1-1,2 mm, binadas, amplamente ovadas, ápice obtuso, vilosas, estramíneas; gluma inferior ausente; gluma superior 1,2-1,6 x 1-1,2 mm, 3-nervada, ápice obtuso, membranácea, não alada, vilosa; antécio inferior neutro; lema inferior 1,3-1,7 x 1-1,2 mm, 3-nervado, ápice obtuso, esparsamente viloso, membranáceo, não plicado; pálea inferior ausente; antécio superior frutífero, 1,3-1,7 x 1-1,2 mm, ovado a amplamente ovado, sem nervuras aparentes, glabro, com pequena rugosidade. Cariopse ca. 0,8 $\mathrm{x}$ $0,7 \mathrm{~mm}$, castanho-claro.

M aterial examinado: 6.III.2006, F.M . Ferreira et al. 949 (CESJ, RB).

Distribuição geográfica e habitat: Espécie amplamente distribuída na A mérica e África tropical, A ustrália, Nova Guiné e Polinésia, em borda de mata, campos ou gramados e locais al terados, de 20-1.100 m de altitude (Renvoize 1984). No PEIB, foi coletada apenas em local de intensa visitação, em borda de mata, à sombra.

41. Paspalum polyphyllum N ees ex Trin., Gram. Panic. 114. 1826.

Fig. 11. E-F.

Plantas perenes, 45-50 cm alt., cespitosas; nós glabros. Bainhas foliares pilosas no ápice, margem inteira, glabrescentes na base; lígula membranosa; prefoliação conduplica- da; lâminas foliares 2,2-9 x 0,2-0,5 cm, lanceoladas, planas, ápice agudo, margem com tricomas tuberculados, base não estreitada, pubescentes em ambas as faces. Inflorescência com 1-3 ramos unilaterais espiciformes, alternos de 2-8 cm compr., axilas hirsutas; ráquis 1-2 mm larg., pubescente, margem não alada, ciliada; pedicelos com tricomas curtos. E spiguetas 2-3 x 0,8-1 mm, binadas ou solitárias, ovais, ápice agudo, alvas; gluma inferior ausente; gluma superior 2-3,1 $x$ 0,8-1 mm, 3-nervada, ápice agudo, pilosa, com tricomas tuberculados longos (2-5 mm compr.) na margem, membranosa, não al ada; antécio inferior neutro; lema inferior 2-2,9 x 0,8-1 mm, 3-nervado, glabro, ápice agudo a subagudo portando curtos tricomas, membranoso; pálea inferior ausente; antécio superior frutífero, 2-3 x 0,8-1 mm, estreitamente elíptico a oval, estramíneo, glabro ou com curtos tricomas no ápice, liso, membranáceo, sem nervuras aparentes; anteras negras. C ariopse não observada.

Material selecionado: 5.V.1987, P. Andrade et al. 955 (BHCB); 19.VI.1991, R.C. Oliveira et al. 1 (CESJ); 8.II.2001, R.C. Forzza et al. 1785 (CESJ); 5.II.2004, R. Dias-M elo et al. 154 (K, RB, SP); 10.III.2004, R.C. Forzza et al. 3131 (K, RB, SP); 30.III.2004, R. DiasM elo et al. 165 (K, RB).

Distribuição geográfica e habitat: ocorre no Paraguai, Uruguai, A rgentina, B olívia e B rasil, de Goiás e M inas Gerais até 0 Rio Grande do Sul (Oliveira \& Valls 2001). No PEIB, foi encontrada entre 1.400 e $1.700 \mathrm{~m}$ de altitude, no campo rupestre de solo arenoso ou em campo encharcável. Os indivíduos ocorrem de maneira isolada ou formando pequenas touceiras.

Pseudechinolaena Stapf, FI. Trop. A fr. 9: 494. 1919.

Gênero relacionado a ambientes florestais e constituído por seis espécies, sendo cinco endêmicas de $M$ adagascar e uma pantropical (Bosser 1975, Renvoize 1984, Clayton \& Renvoize 1986, Judziewicz 1990). No PEIB, está representada por uma espécie.

42. Pseudechinolaena polystachya (K unth) Stapf, FI. Trop. Afr. 9: 495. 1919.

Fig. 12. A-B.

Plantas perenes, 40-50 cm alt., estoloníferas. Bainhas foliares ciliadas nas margens ou hirsútula em toda sua extensão; lígula membranosa; lâminas foliares 1,5-4,5 x 0,5-1,2 $\mathrm{cm}$, oval-lanceoladas, setosas em ambas as faces. Inflorescência 5-17,2 cm compr., de 4-6 ramos unilaterais espiciformes, os inferiores $2-3,5 \mathrm{~cm}$ compr.; ráquis levemente escabra. E spiguetas 2,5-3,5 mm compr.; gluma inferior 2-3 x 1-1,5 mm, 3-nervada com curtos tricomas híspidos, a nervura central prolongando-se em um apículo; gluma superior 2,2-3 x 1,2-1,5 mm, 5-nervada, com tricomas uncinados na maturação e híspido nas imaturas; antécio inferior 2,5-3,5 mm compr., neutro ou masculino, membranáceo ou subcoriáceo, se coriáceo papiloso e com dorso hialino; antécio supe- 


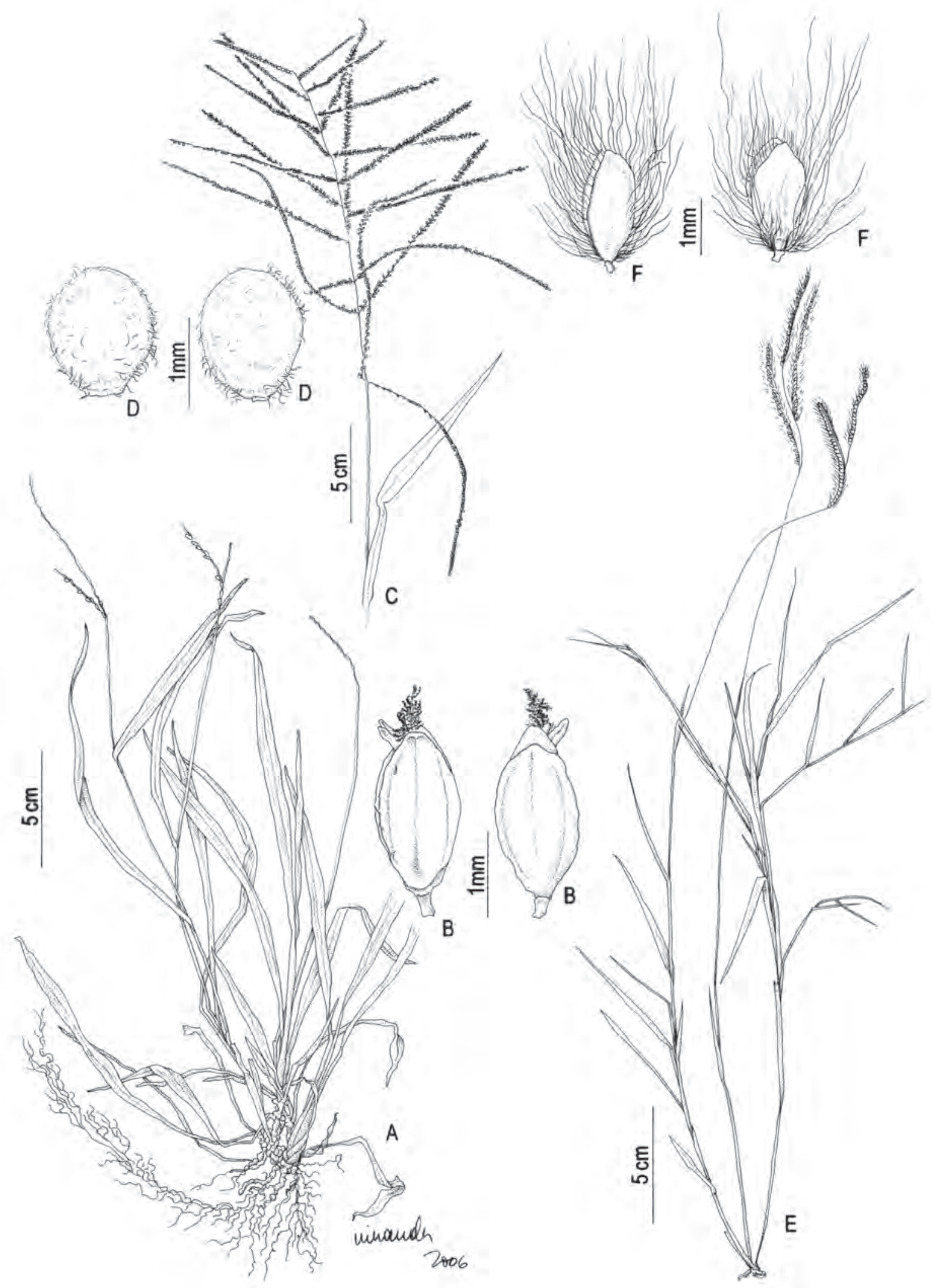

Fig. 11: A -B Paspalum nutans: A . hábito; B. espigueta vista da gluma inferior; B'. espigueta vista da gluma superior. C-D P. paniculatum: C. inflorescência; D. espigueta vista da gluma superior; D'. espigueta vista do lema inferior. E-F P. polyphyllum: E. hábito; F. espigueta vista do lema inferior; F'. espigueta vista da gluma superior. (A -B Dias-M elo 11, D ias-M elo 183; C-D Ferreira 949; E-F Forzza 3131). 
rior frutífero; lema superior 2-2,5 mm compr., coriáceo, liso, brilhoso. Cariopseca. 1,8 x $1 \mathrm{~mm}$, elíptica.

Material examinado: 17.III.2005, R. Dias-Melo et al. 226 (K, $M B M, R B, S P)$.

Distribuição geográfica e habitat: espécie pantropical que ocorre em bordas e interior de mata úmida, em clareiras semisombreadas, capoeira sombreada e em locais al terados (R envoize 1984; L onghi-Wagner 2001c). No PEIB, foi col etada no interior de mata úmida, em local sombreado com solo rico em matéria orgânica, formando uma pequena população.

Steinchisma Raf., Bull. Bot. (Geneve) 1: 220. 1830.

0 gênero Steinchisma é composto por sete espécies de ocorrência restrita as A méricas (do sul dos EUA até a A rgentina), associadas a ambientes úmidos (Zuloaga et al. 2001b). No PEIB, está representado por uma espécie.

43. Steinchisma decipiens (Nees ex Trin.) W.V. Br., M em. Torrey Bot. Club 23(3): 20. 1977.

Fig. 12. C-D.

Plantas perenes ca. $19 \mathrm{~cm}$ alt.; rizomatosas. Bainhas foliares glabras, margem lisa ou com tricomas setulosos em direção ao ápice; colo glabro; lígula membranoso-ciliada; lâminas foliares 2,5-6 x 0,2-0,3 cm, planas, ápice acuminado, margem finamente serreada, face adaxial pilosa a glabrescente, face abaxial glabra. Inflorescência 2-4 cm compr., panícula contraída, espiciforme, cilíndrica, ramos curtos, condensados; ráquis glabra. E spiguetas 1,7-2 × 0,7-0,9 mm, arroxeadas; gluma inferior 0,8-1 mm compr., 3-nervada, ápice subagudo a agudo; gluma superior 1,5-1,8 x 0,4-0,8 mm, (4)- 5-nervada, ápice subagudo a acuminado; antécio inferior neutro; lema inferior 1,6-1,9 x 0,4-0,7 mm, 3-5-nervado, ápice agudo; pálea inferior 1,7-2,2 x 0,7-0,9 mm; antécio superior 1,6-1,9 × 0,4-0,8 mm, papiloso, cartilaginoso. Cariopse não observada.

Material examinado: 3.XI.1991, R.C. Oliveira 61 (CESJ); 19.IX.2006, F.M. Ferreira et al. 1129 (K, RB).

Distribuição geográfica e habitat: espécie sul-americana, encontrada desde a Colômbia e norte do B rasil até o Paraguai, U ruguai, Bolívia e A rgentina, habitando solos úmidos, em bordas de brejos ou lagos, ou ao longo de cursos d'água sobre solo arenoso, desde o nível do mar a $1.600 \mathrm{~m}$ de altitude (Zuloaga et al. 2001b). No PEIB, foi coletado na margem do Rio do Sal to e em campo encharcável na região do M onjolinho.

\section{Índice de exsicatas}

(Os números entre parênteses correspondem à numeração das espécies no texto)
Andrade, P.: 884 (10), 886 (9), 887 (9), 955 (41), 959 (23), 1005 (31), 1048 (31),1176 (14), 1214 (25). Brügger, M.C.: s.n. CESJ 24813 (1), CESJ 24818 (17). Dias-Melo, R.: 8 (9), 9 (18), 10 (10), 11 (39) 15 (26), 16 (2), 18 (29), 138 (26), 139 (34), 140 (10), 141 (17), 142 (9), 143 (25), 144 (17), 145 (6), $146(4), 150(31), 151$ (17), $153(30), 154$ (41), 155 (4), 157 (9), 158 (26), 159 (25), 161 (11), 163 (1), 164 (8), 165 (41), 166 (41), 167 (3), 169 (37), 170 (24), 171 (8), 172 (13), $173(31), 174$ (30), 176 (4), 177 (14), 178 (39), 182 (26), 183 (39), 185 (2), 186 (27),188 (2), 199 (2), 203 (25), 204 (23), 223 (12), 226 (42), 227 (39), 231 (7), 232 (14), 235a (17), 235b (22), 238 (15), 241 (35), 244 (11), 291 (14), 292 (25), 294 (26), 295 (17), 296 (31), 305 (31),. Eiterer, M.: s.n. CESJ 24870 (4), CESJ 25685 (33), CES J 25699 (23), CESJ 25712 (17), CESJ 25717 (3), CESJ 25715 (30), CESJ 25719 (4). Ferreira, F.M .: 565 (21), 566 (15), 567 (19), 573 (25), $574(25), 579$ (9), 582 (9), 584 (17), 585 (3), 586 (17), 587 (15), 588 (17), 593 (17), 595 (17), 596 (2), 597 (17), 601 (17),604 (12), 607 (17), 608 (4), 609 (25), $612(25), 614(26), 615(25), 616(25), 618(6), 677(9), 678$ (15), 686 (5), 723 (39), 947 (32), 949 (40), 951 (20), 952 (21), 953 (38), 954 (19), 981 (25), 985 (37), 986 (39), 992 (18), 1008 (39), 1021 (29), 1022 (36), 1129 (43), 1203 (39), 1204 (32), 1208 (31), 1225 (39), 1237 (33). Forzza, R.C.: 1785 (41), 2696 (25), 3131 (41), 3283 (31), 3296 (26), 3297 (23), 3315 (28), 3549 (31), 3930 (6), 3945 (39), 3946 (25), 3963 (17), 3983 (26), 3996 (31), 4317 (2). G arcia, M. C. M .: 3 (27). Heluey, M.A.: 81 (14), 82 (4), 92 (14). K rieger, L.: s.n. CESJ 8565 (14), CESJ 8543 (23), CESJ 9471 (31), CESJ 25300 (26), CESJ 25302 (9), CESJ 25878 (30). Lisboa, M.L.G.: S.n. CESJ 25889 (10). M arquete, R.: 3584 (25), 3585 (26), 3602 (31). Medeiros, E. S.: 356 (10). Oliveira, R.C.: S.n. CESJ 25202 (8), CESJ 25529 (15), CESJ 32625 (17), CESJ 26221 (25), CESJ 26368 (34), 1 (41), 15 (4), 18 (8), 20 (25), 21 (9), 31 (16), 34 (1), 35 (18), 48 (2), 59 (15), 60 (4), 61 (43), 98 (12), 101 (10), 121 (25), 126 (39), 136 (8), 138 (17), 139 (39), 141 (30), 144 (11), 145 (6), 146 (39), 148 (18), 158 (4), 203 (15). R odela, L .G.: A C14634 (1), Q9-190 (8), RQ1-2 (10), Qd-2 (14), Q2-27 (17), CA Q2-43 (30). Saavedra, M.M .: 199 (41). Salimena, F.R .: s.n. CESJ 24674 (23), CESJ 25468 (12). Souza, H. C.: s.n. BHCB 14584 (27). Viana, P.L.: s.n. CESJ 36822 (9). Verardo, S.M.S.: s.n. CESJ 25367 (2).

\section{Agradecimentos}

A gradecemos ao JBRJ pela estrutura e suporte técnico durante o desenvolvimento deste estudo. A o IEF-M G e a administração do Parque por todo apoio durante os trabalhos de campo. As Dras. Andréa Ferreira Costa, Elsie Franklin Guimarães e aos assessores pela leitura e valiosas sugestões. Os dois primeiros autores agradecem ao CN Pq pelas bolsas do Programa de Taxonomia e a terceira autora pela Bolsa de Produtividade em Pesquisa. 


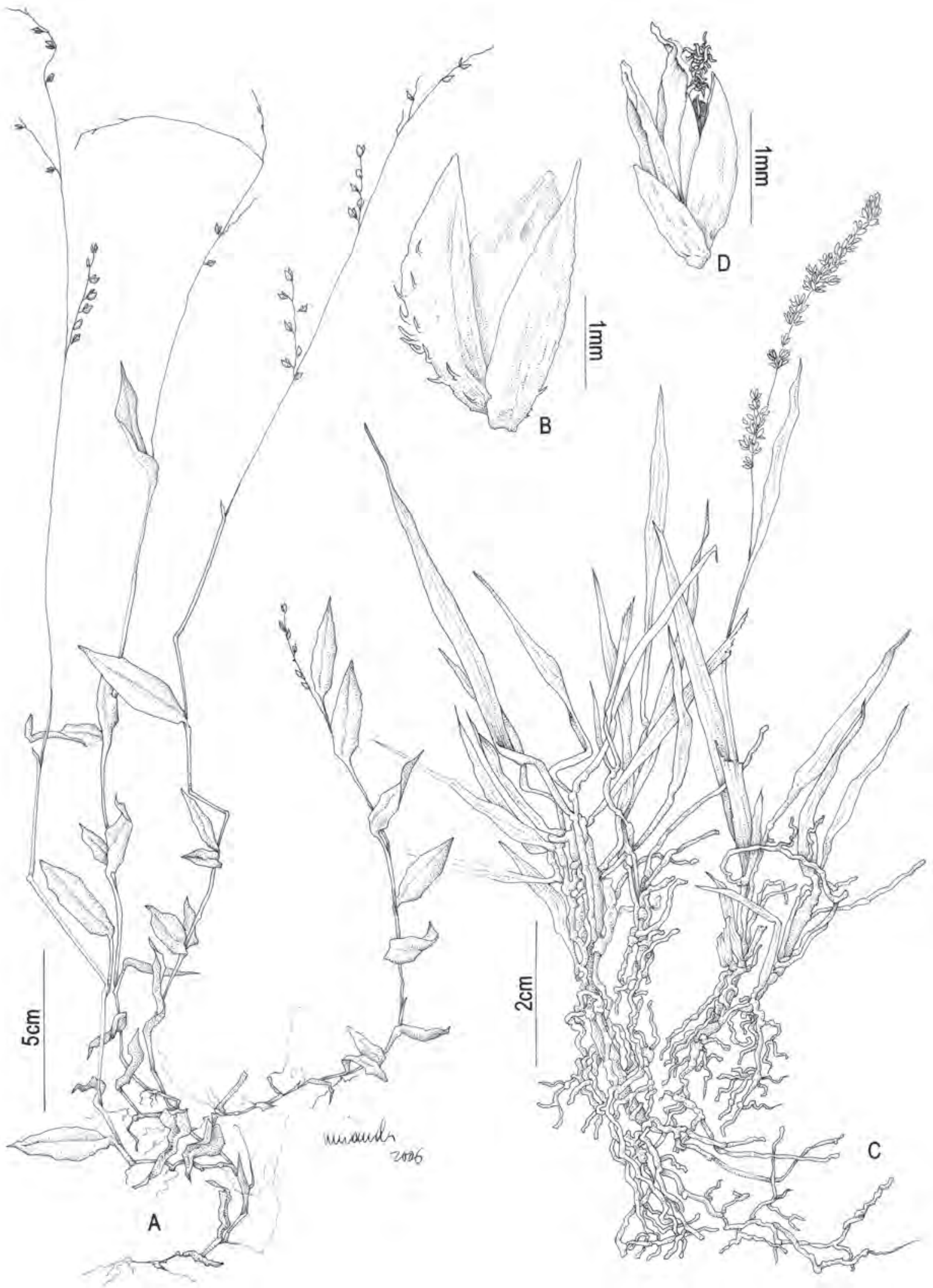

Fig. 12: A-B Pseudochinolaena polystachya: A . hábito; B. espigueta. C-D Steinchisma decipiens: C. hábito; D. espigueta. (A-B Dias-M elo 226; C-D Oliveira 61). 


\section{R eferências}

ALISCIONI, S.S.; GIUSSANI, L.M .; ZULOAGA, F.O. \& KELLOGG, E.A. 2003. A molecular phylogeny of Panicum (Poaceae: Paniceae): tests of monophyly and phylogenetic placement within Panicoideae. Amer. J. B ot. 90(5): 796-821.

ANDRADE, P.M . \& SOUSA, H.C. 1995. Contribuição ao conhecimento da vegetação do Parque Estadual de I bitipoca, Lima Duarte, M inas Gerais. Revta. Árvore 19(2): 249-261.

ARCE, D. \& SAN O, P.T. 2001. M elinis. In H.M. Longhi-Wagner, V. Bittrich, M.G.L. Wanderley \& G.J. Shepherd (eds.). Flora fanerogâmica do Estado de São Paulo - Poaceae. Vol. 1. FAPESP, HUCITEC. São Paulo, p. 165-166.

BOECHAT, S.C. 2005. O gênero Ichnanthus (Poaceae-PanicoideaePaniceae) no Brasil. Iheringia Bot. 60: 189-248.

BOLDRINI, I.I., LONGHI-WAGNER, H.M \& \& BOECHAT, S.C. 2005. M orfologia e taxonomia de Gramíneas Sul-Rio-Grandenses. Editora UFRGS, Porto A legre.

BORGES, R.A.X. 2008. Asteraceae do Parque Estadual do Ibitipoca, M inas Gerais, Brasil: checklist e taxonomia de Astereae. Dissertação de Mestrado. Jardim Botânico do Rio de Janeiro. Rio de Janeiro.

BOSSER, J. 1975. N ote sur les Graminées de M adagascar. IX. Identité dugenre Perullifera A. Camus et revison du genre P seudechinolaena (Hookf.) Stapf. Adansonia 15: 121-137.

BURM A N, A. G. 1985. Nature and Composition of the grass flora of B razil. Willdenowia 15: 211-233.

CA NTO-DOROW, T. 2001. Digitaria. In H.M . Longhi-Wagner, V. Bittrich, M.G.L. Wanderley \& G.J. Shepherd (eds.). F lora fanerogâmica do Estado de São Paulo - Poaceae. Vol. 1. FA PESP, HU CITEC. São Paulo, p. 143-149.

CANTO-DOROW, T.S. \& LONGHI-WAGNER, H.M . 2001. Novidades taxonômicas em D igitaria Haller (Poaceae) e novas citações para 0 gênero no Brasil. Insula 30: 21-34.

CETEC. 1983. Diagnóstico Ambiental de Minas Gerais. Belo Horizonte. CETEC.

CHAPMAN, G. P. 1996. The biology of grasses. London. CA B International.

CLAYTON, W.D. \& RENVOIZE, S.A. 1986. Genera graminum. Kew Bull. A ddit. Ser. XIII. Kew. Royal B otanic Gardens.

DAVEY, J.C. \& CLAYTON, W.D. 1978. Some multiple discriminant function studies on OIpismenus (Gramineae). Kew Bull. 33: 147157.

DUVALL, M.R., NOLL, J.D. \& M IN N, A.H. 2001. Phylogenetics of Paniceae (Poaceae). Amer. J. Bot. 88 (11): 1988-1922.

FERREIRA, F.M., Costa, A.F. \& Forzza, R.C. 2009a. A ristidoideae, Chloridoideae, Danthonioideae e Pooideae (Poaceae) no Parque Estadual de Ibitipoca, M inas Gerais - Brasil. Bol. Bot. U niv. São Paulo 27(2): 000-000.

FERREIRA, F.M., Costa, A.F. \& Forzza, R.C. 2009b. Bambusoideae (Poaceae) no Parque Estadual de Ibitipoca, M inas Gerais - Brasil. Bol. Bot. U niv. São Paulo 27(2): 000-000.

FERREIRA, M.B. \& MAGALHÃES, G.M. 1977. Contribuição para o conhecimento da vegetação da Serra do Espinhaço em M inas Gerais (Serras do Grão-M ogol e da I bitipoca). In Anais XXVI Congresso Nacional de Botânica. Acad. Bras. Ciên. Rio de Janeiro, p. 189-202.

FIL GUEIRAS, T.S. \& LERINA, R. 2001. Saccharum. In H.M . L onghiWagner, V. Bittrich, M.G.L. Wanderley \& G.J. Shepherd (eds.). Flora fanerogâmica do Estado de São Paulo - Poaceae. São Paulo. Vol. 1. FAPESP, HUCITEC. São Paulo, p. 108-110.

FLORES, A.I.P. 2001. Trachypogon. In H.M. Longhi-Wagner, V. Bittrich, M .G.L. Wanderley \& G.J. Shepherd (eds.). F lora fanerogâmi- ca do Estado de São Paulo - Poaceae. Vol. 1. FA PESP, HUCITEC. São Paulo, p. 118-119.

FONTES, M.A. 1997. Análise da composição florística das florestas nebulares do Parque Estadual do I bitipoca, Minas Gerais. Dissertação de M estrado. U niversidade Federal de L avras, M inas Gerais.

GIRA LD 0-CA ÑAS, D. 2001. Sinopsis de la sección Cabrera del género neotropical A xonopus (Poaceae, Panicoideae, Paniceae). Revista Fac. C. Exact. 25: 208-223.

GIULIETTI, A. M., MENEZES, N.L., PIRANI, J.R., MEGURO, M.L. \& WA NDERLEY, M.G.L. 1987. Flora da Serra do Cipó: Caracterização e lista de espécies. Bol. Bot. U niv. São Paulo 9: 1-152.

GOULD, F.W. 1974. Nomenclatorial changes in D ichanthelium (Poaceae). Phytologia 39: 268-271.

GPW (GRASS PHY LOGENY WORKING GROUP). 2001. Phylogeny and subfamilial classification of the grasses (Poaceae). Ann. M issouri Bot. Gard. 88: 373-457.

GUGLIERI,A., LONGHI-WAGNER, H.M.\& ZULOAGA, H.M. 2009. Panicum L. subg. Panicum sect. Rudgeana (Hitchc.) Zuloaga, Panicum subg. Panicum sect. U rvilleana (Hitchc. \& Chase) Pilgere e espécies de Panicum subg. Panicum sem seção definida (Poaceae: Panicoideae: Paniceae) no Brasil. Revta. bras. Bioc. 7: 160-187.

HARLEY, R.M. 1995. Introduction. In B. L. Stannard (ed.). Flora of the Pico das Almas, Chapada da Diamantina-Bahia, Brazil. Royal B otanical Gardens. K ew, p.1-42.

HARLEY, R.M . \& SIM M ONS, N.A. 1986. Florula of M ucugê: Chapada Diamantina-Bahia, Brazil. Royal Botanic Gardens. Kew.

HOLM GREN, P.K., HOLM GREN, N.H. \& BARNETT, L.C. 1990. Index Herbariorum: the herbaria of the world. New York Botanical Garden. New York.

JUDZIEWICZ, E.J. 1990. Poaceae. Fascicle 8. In A.R.A. Görts-Van Rlin (ed.) Flora of the G uianas. ser. A : Phanerogams. K oeltz Scientific Books. Koenigstein.

LAWRENCE, G.H.M. 1951. Taxonomy of vascular plants. M cM illian Co. New York.

LONGHI-WAGNER, H.M. \& TODESCHINI, B.H. 2004. Flora de Grão-M ogol, M inas G erais: Gramineae (Poaceae). Bol. Bot. U niv. São Paulo 22: 143-165.

LONGHI-WA GNER, H.M . 2001a. Tribo A rundinelleae. In H.M . L onghi-Wagner, V. Bittrich, M.G.L. Wanderley \& G.J. Shepherd (eds.). Flora fanerogâmica do Estado de São Paulo - Poaceae. Vol. 1. FA PESP, HUCITEC. São Paulo, p. 119-123.

LONGHI-WAGNER, H.M. 2001b. O plismenus. In H.M . Longhi-Wagner, V. Bittrich, M.G.L. Wanderley \& G.J. Shepherd (eds.). Flora fanerogâmica do Estado de São Paulo - Poaceae. FAPESP, HUCITEC. São Paulo, p. 167.

LONGHI-WA GNER, H.M. 2001c. Pseudoechilonaena. In H.M. Longhi-Wagner, V. Bittrich, M.G.L. Wanderley \& G.J. Shepherd (eds.). Flora fanerogâmica do Estado de São Paulo - Poaceae. Vol. 1. FA PESP, HUCITEC. São Paul 0, p. 231-232.

LONGHI-WAGNER, H.M., BITTRICHI, V., WANDERLEY, M.G.L. \& SHEPHERD, G. (eds.) 2001. Poaceae. In M.G.M. Wanderley, G.J. Shepherd \& A.M. Guilietti (org.). F lora fanerogâmica do E stado de São Paul o. Vol. 1. FA PESP, HU CITEC. São Paulo, p. 1-291.

MENINI NETO, L., ALVES, R.J. V., BARROS, F. \& FORZZA, R.C. 2007a. Orchidaceae do Parque Estadual de Ibitipoca, M G, B rasil. Acta Bot. Bras. 21: 687-696.

MENINI NETO, L., ALVES, R.J.V. \& FORZZA, R.C. 2007b. A subtribo Pleurothallidinae (Orchidaceae) no Parque Estadual de Ibitipoca, M inas Gerais - B rasil. Bol. Bot. U niv. São Paulo 25: 253-278.

MORRONE, O. \& ZULOAGA, F.O. 1991. Estudios morfologicos en el subgénero Dichanthelium de Panicum (Poaceae: Panicoideae: Paniceae) con especial referencia a Panicum sabulorum. Ann. M issouri Bot. Gard. 78: 915-927. 
MORRONE, O., DENHAM, S.S., ALISCIONI, S.S. \& ZULOAGA, F.O. 2008. Parodiophyllochloa, a new genus segregated from Panicum (Paniceae, Poaceae) based on morphological and molecular data. Syst. Bot. 33: 66-76.

MORRONE, O., SCATAGLINI, A. \& ZULOAGA, F.O. 2007. Cyphonanthus, a new genus segregated from Panicum (Poaceae: Panicoideae: Paniceae) based on morphological, anatomical and molecular data. Taxon 56: 521-532.

OLIVEIRA, R.C. 1992. A família Poaceae no Parque Estadual de Ibitipoca, M G. M onografia de Conclusão de Curso. Universidade Federal de J uiz de Fora, M inas Gerais, Juiz de Fora.

OLIVEIRA, R.C. \& VALLS, J.F.M. 2001. Paspalum. In H.M. L onghiWagner, V. Bittrich, M.G.L. Wanderley \& G.J. Shepherd (eds.). Flora fanerogâmica do Estado de São Paulo - Poaceae. Vol. 1. FA PESP, HUCITEC. São Paulo, p. 191-228.

PIRANI, J.R., MELLO-SILVA, R. \& GIULIETTI, A.M. 2003. Flora de Grão-Mogol, M inas Gerais, Brasil. Bol. Bot. U niv. São Paulo 21: 1-24.

POHL, R.W. 1981. Evolution and Systematics of the Gramineae: the twenty-sixty systematics symposium. Ann. M issouri Bot. Gard. 68: 1-3.

RADFORD, A.E., DICKINSON, W.C., MASSEY, J.R. \& BELL, C.R. 1974. Vascular plant systematics. Harper \& R ow. New York.

RENVOIZE, S.A. 1995. (Gramineae) Poaceae. In B. L. Stannard, (ed.) Flora of the Pico das Almas Chapada da Diamantina-Bahia, Brazil. Royal Botanical Gardens. Kew, p. 704-719.

RENVOIZE, S.A. 1984. The Grasses of Bahia. The Royal Botanical Gardens, Kew.

SALIM ENA-PIRES, F.R.G. 1997. A spectos fisionômicos e vegetacionais do Parque Estadual de Ibitipoca, M inas Gerais, Brasil. In G.C. Rocha (coord.) Anais do 10 Seminário de Pesquisa sobre o Parque Estadual de Ibitipoca. Núcleo de Pesquisa em Zoneamento A mbiental da UFJ F, Juiz de Fora, p. 51-60.

SANTOS, C.A.G. \& SANO, P. 2001a. Echinolaena. In H.M. LonghiWagner, V. Bittrich, M.G.L. Wanderley \& G.J. Shepherd (eds.). Flora fanerogâmica do Estado de São Paulo - Poaceae. Vol. 1. FAPE SP, HUCITEC. São Paulo, p. 152-153.

SANTOS, C.A.G. \& SANO, P. 2001b. Homolepis. In H.M. LonghiWagner, V. Bittrich, M.G.L. Wanderley \& G.J. Shepherd (eds.) Flora fanerogâmica do Estado de São Paulo - Poaceae. Vol. 1. FAPESP, HUCITEC. São Paulo, p. 154-155.

SEDE, S.M., MORRONE, O., GIUSSANI, L.M. \& ZULOAGA, F.O 2008. Phylogenetic studies in the Paniceae (Poaceae): a realignment of Section Lorea of Panicum. Syst. Bot. 33: 284-300.

SEDE, S.M., ZULOAGA, F.O. \& M ORRONE, O. 2009. Phylogenetic studies in the Paniceae (Poaceae: Panicoideae): 0 cellochloa, a new genus from the N ew World. Syst. B ot. (prelo).

STIEBER, M .T. 1982. R evision of I chnanthus sect. I chnanthus (Gramineae, Panicoideae). Syst. Bot. 7: 85-115.

TÜRPE, A. M . 1984. Revision of the South A merican species of Schizachyrium (Gramineae). Kew Bull. 39: 169-178.

VALLS, J.F.M., LONGHI-WAGNER, H.M.\& BOLDRINI, I.I. 2001. Axonopus. In H.M. Longhi-Wagner, V. Bittrich, M.G.L. Wanderley
\& G.J. Shepherd (eds.). F lora fanerogâmica do Estado de São Pau10 - Poaceae. Vol. 1. FA PESP, HU CITEC. São Paulo, p. 129-141.

WATSON, L.\& DALWITZ, M.J. 1992. The grass genera of the world. C.A.B. International, Cambridge.

ZANIN, A. 2001a. Andropogon. In H.M. Longhi-Wagner, V. Bittrich, M.G.L. Wanderley \& G.J. Shepherd (eds.). Flora fanerogâmica do Estado de São Paulo - Poaceae. Vol. 1. FA PESP<HU CITEC. São Paulo, p. 91-96.

ZANIN, A. 2001b. Schizachyrium. In H.M . L onghi-Wagner, V. Bittrich, M.G.L. Wanderley \& G.J. Shepherd (eds.). F lora fanerogâmica do Estado de São Paulo - Poaceae. Vol. 1. FA PESP, HUCITEC. São Paulko, p. 111-112.

ZANIN,A.\& LONGHI-WA GNER, H.M . 2006. Sinopse do gênero Andropogon L. (Poaceae-Andropogoneae) no Brasil. Revista Brasil. Bot. 29: 289-299.

ZAPPI, D.C., LUCAS, E., STANNARD, B.L., LUGHADHA, E.N., PIRANI, J.R., QUEIROZ, L.P., ATKINS, S., HIND, D.J.N., GIULIETTI, A.M., HARLEY, R.M. \& CARVALHO, A.M . 2003. Lista das plantas vasculares de Catolés, Chapada Diamantina, Bahia, B rasil. Bol. Bot. U niv. São Paulo 21: 345-398.

ZULOAGA, F.O. 1987. Systematics of N ew World species of Panicum (Poaceae: Paniceae). In: T.R. Soderstrom, K.W. Hilu, C.S. Campbell \& M.E. Barkorth (eds.). Grass systematics and evolution. Smithsonian Institution Press. Washington, p. 287-306.

ZULOAGA, F.O. \& SENDULSKY, T. 1988. A revision of Panicum subgenus Phanopyrum section Stolonifera (Poaceae: Paniceae). Ann. M issouri Bot. Gard. 75: 420-455.

ZULOAGA, F.O., ELLIS, R. P. \& MORRONE, O. 1993. A revision of Panicum subgenus Dichanthelium section Dichanthelium (Poaceae: Panicoideae: Paniceae). Ann. M issouri Bot. Gard. 80: 119-190.

ZULOAGA, F.O., MORRONE, O., VEGA, A.S. \& GIUSSANI, L.M. 1998. Revisión y análisis cladístico de Steinchisma (Poaceae: Panicoideae: Paniceae). Ann. M issouri Bot. Gard. 85: 631-656.

ZULOAGA, F.O., M ORRONE, 0.\& GIUSSANI, L. 2000. A cladistic analysis of the Paniceae: a preliminary approach. In S.W.L. Jacobs $\&$ J. Everett (eds.) Grasses: systematics and evolution. CSIRO. M el bourne, p. 123-135.

ZULOAGA, F.O, GU GLIERI, A. \& LONGHI-WAGNER, H.M . 2001 . Panicum. In H.M. Longhi-Wagner, V. Bittrich, M.G.L. Wanderley \& G.J. Shepherd (eds.). F lora Fanerogâmica do E stado de São Pau10 - Poaceae. São Paulo, Hucitec. 1: 168-190.

ZULOAGA, F.O., GUGLIERI,A.\& LONGHI-WAGNER, H.M. 2001b. Steinchisma. In H.M . L onghi-Wagner, V. Bittrich, M.G.L. Wanderley \& G .J. Shepherd (eds.). Flora Fanerogâmica do Estado de São Paulo - Poaceae. São Paulo, Hucitec. 1: 238-239.

ZULOAGA, F.O., M ORRONE, O., DAVIDSE, G., FILGUEIRAS, T.S., PETERSON, P.M., SORENG, R.J. \& JUDZIEWICZ, E.J. 2003. Catalogue of New World Grasses (Poaceae): III. Subfamilies Panicoideae, A ristidoideae, A rundinoideae and Danthonioideae. Cont. U. S. Natl. Herb. 46:1-662.

ZULOAGA, F.O., GIUSSANI, L. \& M ORRONE, 0. 2006. On the taxonomic position of Panicum aristellum (Poaceae: Panicoideae: Paniceae). Syst. Bot. 31: 497-505. 